Trakya Eğitim Dergisi

Cilt 9, Sayı 2

Mayıs 2019, 260-286

Geliș Tarihi: 25.10 .2018

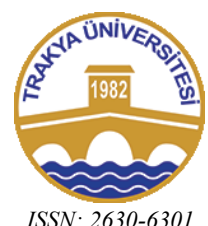

ISSN: 2630-6301
Trakya Journal of Education

Volume 9, Issue 2

May 2019, 260-286

Doi: $10.24315 /$ tred. 474891

Yayına Kabul Tarihi: 25.05.2019

\title{
Teoriden Uygulamaya Argümantaston Tabanlı Bilim Öğrenme (ATBÖ) Yaklaşımı: Kimya Laboratuvarlarında Uygulama Örneği
}

\author{
The Science Writing (SWH) Approach from Theory to Practice: Implementing in \\ Chemistry Laboratories
}

\author{
Fatma YAMAN ${ }^{1}$, Ali ÇIKMAZ ${ }^{2}$, Erçin ŞAHİN ${ }^{3}$, Brian HAND ${ }^{4}$
}

\begin{abstract}
Öz: Bu çalışmanın amacı, Argümantasyon Tabanlı Bilim Öğrenme yaklaşımını (ATBÖ) teorik olarak açıklamak, yazılı ve sözlü argümanların nasıl gerçekleştiğini örnek bir uygulama üzerinden göstermeye çalışmaktadır. Bu bağlamda, fen öğrenmede bilimsel bilginin oluşturulması sürecinde dilin etkin bir şekilde nasıl kullanıldığ1, yazılı ve sözlü argümantasyonların nasıl oluşturulduğu ve öğrenme ortamlarının bunlara nasıl bir katk1 sağladığı açıklanmıştır. Ayrıca, ATBÖ yaklaşımının argüman fazı genel kimya laboratuvalarında kimyasal denge konusu örnek alınarak detaylı bir şekilde açıklanmaya çalışılmıştır. Yapılan örnek açıklamalar neticesinde, bu yöntemi uygulamak isteyen araştırmacı ve öğretmenlere çeşitli önerilerde bulunulmuştur.
\end{abstract}

Anahtar sözcükler: Argümantasyon tabanlı bilim öğrenme, yazılı ve sözlü argümanlar, kimya laboratuvarı

\begin{abstract}
The purpose of this study is to explain the theoretical perspectives of an argument-based science inquiry approach, also known as The Science Writing Heuristic (SWH), and to represent how oral and written arguments take place using an example of its implementation. In the context of constructing scientific knowledge, we discuss how language is used, how oral and written arguments are constructed, and how the learning environment contributed to learning by providing an example on chemical equilibrium in a general chemistry laboratory with the emphasis on the argument phase. Then, some implications are provided for researchers and teachers who want to implement this approach.
\end{abstract}

Keywords: The Science Writing Heuristic approach, written and oral arguments, chemistry laboratory

\section{EXTENDED ABSTRACT}

The purpose of this study is to explain theoretical perspectives of an immersive approach to argument-based science inquriy, also known as Science Writing Heuristic, and to represent how oral and written arguments take place using an example of its implementation. In the context of constructing and criticizing scientific knowledge, we explain how language is used, how oral and written arguments are constructed, and how the learning environment contribute to learning by providing an example on chemical equilibrium in a general chemistry laboratory with the emphasis on argument phase.

The SWH provides students with oppurtunities to pose questions, determine design, gather data, make claims based on evidence, and check their assertions against current norms. In this context, students are engaged with multiple representations, such as pictures, text, graphs, or equations, as well as negotiating across multiple situations that arise in the lab. Throughout the learning process, students are required to negotiate in small and whole groups. In small groups, students work collobaratively to pose questions, determine design, discuss their data and use reasoning to generate evidence. Then they engage with whole class discussion to defend or debate their claims and evidence. Throughout this procedure, students engage with constructing and criticizing their knowledge claims by participating in the multiple oral and written negotiations that form the basis of the epistemic practices both of science and language. Moreover, students engage with Premise-Justification-Conclusion (P-J-C) procedure.

\footnotetext{
${ }^{1}$ Dr. Öğr. Üys., Yozgat Bozok Üniversitesi, Eğitim Fakültesi, fatmayaman@ymail.com, ORCID: 0000-0002-4014-3028

${ }^{2}$ Arș. Gör., Iowa Üniversitesi, Eğitim Fakültesi, ali-cikmaz@uiowa.edu, ORCID: 0000-0001-7196-1085

${ }^{3}$ Arş. Gör., Iowa Üniversitesi, Eğitim Fakültesi,ercin-sahin@uiowa.edu, ORCID: 0000-0003-3491-1235

${ }^{4}$ Prof. Dr., Iowa Üniversitesi, Eğitim Fakültesi, brian-hand@uiowa.edu, ORCID: 0000-0002-0574-7491
} 


\section{SWH Laboratory-What Does It Look Like? Beginning}

Before students arrive to the lab, they prepare their beginning question(s), BQs, outline their design, list their safety concerns and construct their pre-concept map for the activity.

\section{SWH Laboratory-What Does It Look Like? During}

When students arrive to the lab, they discuss their beginning questions as groups, every group writes their BQs on the board, and through a whole class discussion determine their class BQs. Then whole class discuss their design and divide into groups to answer and investigate their BQs. Students draft appropriate data collection tables, including dependent and independent variables to be investigated. In this context, in the Beginning Questions phase the students are required to write a question or questions that can be investigated experimentally, and that demonstrate understanding of independent and dependent variables, a generalization or an appropriate application of lab results. In Design Section, students are required to list the steps that they will implement the experiment. In the safety section, students list the major safety concerns for the experiment they will perform. In the Data section, students implement experiments and do observations, list all data, take notes, make calculations, write equations, chemical information etc. After students collect all their data, they try to analyze them. In this context, they look for patterns and anomalies, they generate graphs, they enter their data to the blackboard, and then they discuss results. Throught this procedure, the instructor moves among the groups, ask guiding questions or redirect students to their classmates, facilities discussion without telling students what they should learn from the experiment.

\section{SWH Laboratory-What Does It Look Like? End}

After discussing the results students make their claims and support their claims with evidence. In this context, Claim is one- or two-sentence statement, which answer the beginning questions, derived from the results of the laboratory work. When students make a claim for an investigation, they are expected to note a pattern, demonstrate a generalization, articulate a relationship, or provide an explanation that they have uncovered by their work. Evidence is a written explanation that supports the claims. Students display scientific argumentation and reasoning skills to state a claim and provide rational evidence for the claims. Students use chemical equations, calculations, and graphs to explain and interpret the meaning behind the data and calculations. They are expected to use proper Turkish to write logical statements. Throughout this procedure, students are encouraged to make explicit associations among questions, observations, data, claims, and evidence as well as to be able to defend their position.

\section{SWH Laboratory-What Does It Look Like? After Lab}

After lab investigation, students are required to search at least three resources including their textbook, the İnternet, other reference books etc, to explain, confirm or dicount what they have learned from the lab. They also construct a post concept map. In the Reflection section, students are expected to compare their results to other groups, teachers, textbooks, and other sources, and discuss how their ideas have been changed or not. Moreover, they are required to write pragraphs using proper Turkish with clear logical statement, define and interpret their evidence. Students are expected to refer the information they found.

The SWH has some benefits in terms of learning. These are:

- Students work collebaratively and engage with individual, small group and whole class discussions.

- Students' oral and written arguments increase over the time.

- Students use multiple representations for their oral and written arguments.

- Students are required to use logical statements.

- Students' critical thinking, cognitive and metacognitive skills develop over time. 


\section{GIIRIŞ}

Fen eğitiminin temel amaçlarından biri fen okuryazarı bireyler yetiştirmektir. Öğrenmenin nasıl gerçekleştiğini açıklamaya yönelik kuramların davranışçılıtan yapılandırmacılığa evrilmesiyle, fen okur-yazarlığı kavramının tanımı da değişmiştir. Önceleri, bilimsel kitapları okuyabilme ve bilimsel kelimeleri doğru şekilde kullanabilme fen okuryazarlığı olarak tanımlanırken, güncellenen (yenilenen) öğretim programlarında bilimsel okuryazar birey, ilgili konularda genel tartışmalara aktif olarak katılabilen, bilimsel ve teknolojik bilgilerini gündelik hayatlarında dikkatli bir şekilde kullanabilen ve okul sonrası da bilim öğrenmeyi sürdürebilen birey olarak tanımlanmıştır (NRC, 2007; 2012). Fen okuryazarı bireyleri yetiştirme konusunda düşülen hataların başında öğrencilere bilimin nasıl yapıldığını tecrübe edebilecekleri firsatların sunulmaması gelmektedir (NRC, 2012). Bunun üstesinden gelmek için yenilenen öğretim programlarında öğrencilerin bilim öğrenme esnasında yapması gereken bilimsel pratikler belirtilmiştir (NRC, 2012; MEB, 2013). Bu pratikler "bireyin kendi sorularından yola çıarak modeller geliştirip kullanabilmesi, araştırma yöntemini planlayarak uygulayabilmesi, elde ettiği verileri çözümleyerek yorumlayabilmesi, matematiksel hesaplamaları uygun olarak kullanabilmesi, açıklamalar oluşturabilmesi, kanıtlara dayanarak argüman geliştirebilmesi ve elde ettiği bilgiyi değerlendirebilmesi ve iletişimde kullanabilmesi” şeklinde özetlenmiştir. Burada beceri yerine pratik kelimesi kullanılmasının sebebi, "bilimsel araştırmalarda sadece beceri değil her bir pratiğin kendine özgü yapısının da bilinmesinin gerekli olduğunu vurgulamak" olarak açıklanmıştır (NRC, 2012). Bilimsel pratikler beraber değerlendirildiğinde üç konu ön plana çıkmaktadır: öğrenme ortamında dil kullanımı, argümantasyon tabanlı araştırma-sorgulama ve bunları bir araya getirerek öğrenmeye olanak sağlayan ortam.

\section{1. Ögrenmede Dilin Rolü}

İlgili alanyazın incelendiğinde, dil olmadan bilim yapmanın mümkün olmadığı, dilin yalnızca bilimsel bilginin transferi için değil aynı zamanda onun oluşturulması sürecinde aktif bir şekilde kullanıldığ 1 görülmektedir (Norris \& Philips, 2003). Fen öğrenimi/öğretiminde dilin fonksiyonu ve kullanımı ile ilgili tartışılan iki farklı görüş bulunmaktadır. Bunlar, "dili kullanmak için öğrenme" ve "öğrenmek için dili kullanma" görüşleridir (Hand, 2008). Bu görüşlerden birincisi olan "dili kullanmak için ögrenme" yaklaşımına göre, hangi disiplinde bilim yapılacaksa o disiplinde kullanılan dil ve öğeleri öğrenildikten sonra bilim/fen öğrenimi aşamasına geçilmelidir (Halliday \& Martin, 2003). Örneğin, ögrenci bir laboratuvar uygulaması yapacak ve onu raporlaştıracaksa, öncelikle laboratuvar raporu nasıl olmalı, nasıl bir dil kullanılmalı bunları öğrendikten sonra uygulama aşamasına geçmelidir. İkinci görüş olan "öğrenmek için dili kullanma" yaklaşımında ise öğrenme deneyimi ile dil kullanımının birbiri içinde beraber gelişecek şekilde yapılması gerektiği vurgulanmaktadır (Gee, 2004). Bu görüşe göre dilin nasıl kullanılacağını öğrenmek ile fen öğrenimi arasında bir ayrım bulunmamaktadır. Böylelikle, birinci görüşe göre dil öğrenilmesi gereken bir olgu iken, ikinci görüşte dil öğrenmeyi sağlayan bir araç olarak görülmektedir (Hand, 2008).

Dil kullanımı konuşma, dinleme, okuma ve yazma gibi değişik formlarda gerçekleşmektedir (Norton-Meier, 2008). Klein'ın (1999) kapsamlı alanyazın incelemesine göre, dilin kullanımının öğrenilmesinin bağlamdan bağımsız olarak düşünen yaklaşımların kullanılmasının faydasına dair kesin bir sonuç bulunamamıştır. Ayrıca, Prain'in (2006) alanyazın incelemesi, öğrenmek için dili araç olarak kullanma yaklaşımının daha verimli öğrenmeyi desteklediğini göstermektedir. Bilim ve dil ile ilgili bu iki yaklaşım tartışılırken, Hand ve Prain (2006), her ikisinin arasında bir geçiş pozisyonu önermişlerdir. Öğrencilerin içeriği öğrenirken dili bir öğrenme aracı olarak kullanmalarının öneminin yanında, bireyin bilimsel yazı tarzını da anlamalarının gerekliliğini vurgulamışlardır. Bu önerinin yanında gündelik dil ile bilim dilinin bir arada kullanılmasının anlamlı öğrenmenin gerçekleşmesi için bir gereklilik olduğuifade edilmiştir (Hand \& Prain, 2006). Bireyin gündelik dilinin aktif kullanılması ile ön bilgilerinin açığa çıkması; öğretmen, ögrenci ve diğer kaynaklar ile aktif müzakere sonucu yeni bilgilerin inşası sürecinde günlük dilden bilimsel dile yumuşak bir geçişin sağlanması ve bunların dilin farklı formları olan konuşma ve yazma aktivitelerinin kullanımı ile desteklenmesi bilimsel kavramları öğrenmede faydalı bir yaklaşım olarak belirtilmiştir (Wallace, Hand \& Prain, 2004; Yore \& Treagust, 2006). 
Wellington ve Osborne (2001) bilimsel düşünme ve ak1l yürütmenin önemine vurgu yaparken, bunların gelişmesi için bireyin bilim dilini ve kavramlarını kullanabilme becerisini ön plana çıkarmaktadır. Bunun yanında, Bransford, Brown ve Cocking (1999) ise dilin öğrenmeye olan etkisini, dil kullanımının bireyin anlamlandırabilme yapmasına olanak sağlayan bir kavram olmasından ileri geldiğini savunmuştur. Ayrıca, öğrencinin (1) kanıtlarını savunabilme becerilerinin gelişmesinde dilin öneminin, (2) akranlarından öğrenirken ve bilgiyi paylaşırken diyaloğun gerekliliğginin ve (3) bilimsel alana özgü kullanılan dil unsurlarının, kavramların derinlemesine anlaşılmasını sağladığının farkına varmasının gerekliliği belirtilmiştir. Bu yüzden, bilim ve fen öğreniminin temeli olan araştırmasorgulamada, dilin bir öğrenme aracı olarak ele alırken, dilin kullanıldığı bir form (Norton-Meier, 2008) olan argümantasyonunda vurgulanması gerekir.

\subsection{Argümantasyon ve Bilimsel Bilginin Yapılandırılması}

Argümantasyon, bilginin kritik edilerek yapılandırılmasını sağlayan sosyal bir müzakere (negotiation) süreci olarak tanımlanmıştır. Bu süreçte bireyler belli bir konu hakkında soru sormakta, sorularına cevap oluşturacak şekilde veri toplamakta, verilerden yola çıkarak iddialarını oluşturmakta ve bu iddiaları savunacak deliller ortaya koymaktadır. Sonrasında ise görüş birliğine varmak için belirli bir topluluk içerisinde, bu argümanlar kritik edilerek bilginin yapılandırılması sağlanmaktadır (Driver, Newton \& Osborne, 2000; Ford, 2012). Müzakere sonucu görüş birliğine varmak için argümanların yapılandırılması ve kritik edilmesi arasındaki diyalektik etkileşim çok önemlidir (Ford, 2012). Bilim insanları oluşturdukları argümanların zayıf yanlarını görmek ve bunları güçlendirmek için, oluşturdukları argümanları diğer bilim insanlarının kritik ve eleştirilerine sunarlar. Bu sebepten, kritik etme bilimsel pratiklerle vurgulanan bilginin yapılandırılmasına, yani anlamlı öğrenmeye olanak sağlar. Diğer bir ifadeyle, alanda uzmanları ile tartışılıp kritik edilmesine firsat verilmeyen argümanın, alanda kabul gören bir bilimsel bilgi olarak yapılandırılması mümkün değildir. Bilim öğretiminde kritik etmenin rolü öğretim programlarında da vurgulanmış ve şöyle denmiştir: "kritik etme genelde bilginin inşa edilmesi, özelde ise bilim öğrenimi için temel yapı taşıdır” (NRC, 2012, s.44).

Bilgiyi inşa etme sürecindeki önemli rolüne rağmen, öğrenciler için kritik etme kolay bir iş değildir. Bunun sebebi olarak neyin veri, neyin kanıt, neyin iddia ve neyin tutarlı bir argüman olarak kabul edilmesi hususunda epistemik kavrayış eksikliği gösterilmiştir (Duschl, 2008). Yani, öğrencilerin, argümantasyon yaparken, bilimde neyin yüksek seviye argüman olarak tanımlandığı konusunda çok yönlü ve gelişmiş bir kavrayışa sahip olmaları gerekir (Mason \& Scirica, 2006). Dahası, öğrenciler birbirlerinin fikirlerini kritik edebilecek anlayışta olmalıdırlar (Sandoval \& Millwood, 2008). Diğer bir ifadeyle, öğrenci (1) soru oluşturmak, (2) veri toplamak, (3) verileri yorumlayarak iddia ve iddiasını destekleyecek kanıtlar oluşturmak ve (4) bu iddialarını herkesin önünde tartışabilmek için nelerin araç olabileceğini epistemik olarak kavramalıdır. Argümantasyonun araştırma-sorgulamanın özgün bir formu olduğu göz önünde bulundurulduğunda (Hand, 2008; Walton, 1998), argüman, sadece araştırma-sorgulama sonucu oluşan son ürün değil, aynı zamanda öğrencilerin soru ürettiği, deneyler yaptığı, verileri analiz ettiği, kanıtlara dayalı olarak iddialarını oluşturduğu ve bunları yaparken her aşamada karşılaştı̆̆ bilgileri kritik ederek kendi bilgi dağarcığını geliştirdiği bir süreç şeklinde araştırma-sorgulamanın temelini oluşturur (Klein, 2006). Bu açıdan, argüman, öğrencileri araştırmasorgulama sürecine dahil eden ve bilimsel pratikleri kavramalarına sebep olan bir araç haline dönüşmektedir. Bilim yaparken argümanın, iddia ve kanıtı içermekle beraber, araştırma-sorgulamaya rehberlik eden soru ile de uyumlu olması gerekir. Bu yüzden, fen sınıflarında bilimsel argümantasyon ele alınırken argümanın soru-iddia-kanıt üçlüsünden oluştuğu göz ardı edilmemelidir (Hand, 2008).

Soru, yapılacak incelemeye temel teşkil eden soru zamiri formunda bir ifade iken, iddia, soruya cevaben çözüm, sonuç ya da pozisyon belirten bir ifadedir. Kanıt ise, iddiada belirtilen çözüm, sonuç, ya da pozisyonun açıklamasıdır. Burada özellikle anlaşılması gereken husus öğrencilerin veriden akı1 yürüterek (Veri+Akıl Yürütme $=$ Kanıt) kanıta ulaştığı gerçeğidir. Bir başka ifadeyle, veri ile kanıt aynı şey değildir. İkna edici argüman oluşturmak için bu bileşenlerin herbirinin tek başına çok önemli olmasının yanında (McNeill, Lizotte, Krajcik \& Marx, 2006; Sampson, Grooms \& Walker, 2011), kaliteli argüman meydana getirmek ve bilim öğrenimini teşvik etmek için, soru-iddia-kanıtın uyumlu bir şekilde bir araya getirilmesi öğrenme için hayati öneme sahiptir. Diğer bir söyleyişle, iddia mutlaka bir soruya cevap olmalı, bunu yaparken de kanıt ile desteklenmelidir. Argümanın ana yapı itibarı ile soru-iddia-kanıt olarak yapılandırılmasının yanında her bir bileşeninin öğrencilerin öncül- 
gerekçelendirme-çıkarım (Walton, 2016) şeklinde akıl yürütülerek yapılandırılması öğrenmenin sahiplenilerek daha kalıcı olmasına olanak sağlar (Hand, Norton-Meier \& Jang, 2017). Argümantasyonun amacı muhatabını ikna etmek için savunduğun görüşü gerekçelendirmektir (Walton, 2016). Öğrenciler araştırma sorularına karar verirken soruların neden seçildiğini gerekçelendirmektedir. Belirlenen sorulara cevap vermek için yapacakları deneyin ve dizaynların neden seçildiğini sorgulamaktadır. Böylelikle, dersin her anında yapılan işlemin ve ortamda karşılaşılan her bilginin sorgulanmasıyla akıl yürütme dersin her anına yayılmaktadır Böylece argümantasyon dersin belli bir bölümünü oluşturan bir yapı olmaktan ziyade dersin tamamına hakim olan, bireyi her zaman bilişsel olarak aktif olmaya teşvik eden bir yaklaşıma dönüşmektedir (Şekil 1). Bireyin bilimsel bilgiyi yapılandırırken sürekli karşılaştığı bilgi selini sorgulaması, gerekçelerini araştırması ve ortama reaksiyon vermesi bireyi anlayarak kalıcı öğrenmeye yönlendirecektir. Bu bağlamda, öğrenme ortamının, bahsedilen bileşenleri bünyesine alacak ve onların aktif olarak kullanılmasını teşvik edecek şekilde dizayn edilmesi gerekir.

\section{3 Öğrenme Ortamlarının Kompleks Yapısı}

Bilim öğrenme ortamları, anlamlı ve kalıcı öğrenmeyi desteklemek için, dil kullanımını teşvik eden (Prian \& Hand, 2016) ve argümantasyon temelli yoğun diyalog içeren (Mercier \& Sperber, 2011) ortamlar şeklinde dizayn edilmelidir. Böyle ortamların farklı başarı düzeyindeki öğrencilerin öğrenmesini teşvik ederek, alt düzey öğrencilerin öğrenme seviyesini artırdığı ve başarı farkını azalttığı araştırmalarla ortaya koyulmuştur (Chanlen, 2013). Bilimin gelişimi, belirli bir disiplindeki bilim insanlarının bilimsel müzakereler yapabildiği diyalog ortamlarında gerçekleşir. Böyle ortamlar, akı1 yürütme ve bilimsel içeriğin tartışıldığ 1 ve bilimsel gelişim için önemli yapıtaşlarından olan epistemik güven ve uyanıklığın vurgulandığı yerlerdir (Mercier \& Sperber, 2011). Yani, diyaloğun hakim olduğu ortamlar, katılımcıların bilimsel argüman yapısını kullanmalarını gerektirmektedir. Ayrıca bu ortamlar, katılımcıların kritik etme ve bilim yapmanın gereği olan karşıt argüman geliştirmelerini sağlamaktadır. Diyalog ortamları, öğrencilerin etkileşiminde kişilerin değil fikirlerin tartışıldığı, öğrencinin aktif katılımcı olduğunda kazanımlarının daha fazla olduğunu farkettikleri (kazanç-kayıp oranı) (Mercier \& Sperber, 2011) bilimin doğası ve yapılandırmacılık kuramı gereği bireyin bilginin yapılandırılmasında kendisinin ve ortamdaki diğer aktörlerin aktif rolünün farkına vardığı yerlerdir (Ford \& Forman, 2006).

Cavagnetto (2010), kapsamlı alanyazın incelemesinde argümantasyon tabanlı bilim öğrenme yaklaşımlarını inceleyerek, argümantasyonun bireylerin eleştirel düşünme, üstbilişsel düşünme ve iletişim becerilerini geliştirdiğini belirtirken, bazı argümantasyon yaklaşımlarının bilimsel pratikleri ve dolayısıyla fen okuryazarlığını daha fazla desteklediği sonucuna varmıştır. Argümantasyon tabanlı yaklaşımları üç başlık altında sınıflandırmıştır: kültürlenme-odaklı (immersive-oriented), yapı-odaklı (structure-oriented), ve sosyobilimsel-odaklı (socioscientific-oriented). Kültürlenme-odaklı yaklaşımlar argümantasyonu bilim öğrenmenin doğal bir parçası olarak benimseyip, uygulayarak öğrenilmesi gerektiğini vurgularken; yapı-odaklı yaklaşımlar, argümantasyonun bağlamından bağımsız olarak öğrenilerek daha sonra bilim öğreniminde kullanılması gerektiğini ifade eder. Sosyobilimselodaklı uygulamalar ise genelde tartışmalı konular olan toplum tarafından farklı kabuller gören bilimsel konuları bağlam olarak ele alıp öğrencilerin argümanlarına bir amaç kazandırmaktadır. Sosyobilimsel yaklaşım, bağlam odaklı ve kısmi olarak politik tutumlarla ilgilidir. Bu sebepten, bu yaklaşımın sınıf ortamında uygulanmasının uygun olmadığı belirtilmiştir ve diğer iki yaklaşıma odaklanılmıştır. Güncellenen öğretim programlarında bilimin yaparak-yaşayarak öğrenilmesinin gerekliliği vurgulandığ 1 gibi, bilimsel bilginin yapılandırılmasında önemli bir bileşen olan argümantasyonun da yaparak-yaşayarak kendi bağlamı içerisinde öğrenilmesi gerekir. Bu bağlamda, Cavagnetto (2010) da bu hususu vurgulayarak, argümantasyon yaklaşımları arasında, kültürlenme-odaklı yaklaşımın bilimsel pratiklerin tamamını bünyesinde barındırdığı için, fen okuryazarlığının gelişimi konusunda en umut vadeden yaklaşım olduğunu iddia etmektedir.

\subsection{Argümantaston Tabanlı Bilim Öğrenme (ATBÖ) Yaklaşımı}

Kültürlenme-odaklı yaklaşımlarından Science Writing Heuristic, Türkçe'ye "Argümantasyon Tabanlı Bilim Öğrenme” (ATBÖ) şeklinde çevrilmiştir (Yeşildağ-Hasançebi \& Günel, 2013). Son yıllarda, АTBÖ ile, Amerika Birleşik Devletleri, Güney Kore gibi ülkelerin yanısıra Türkiye'de de hem uygulama, hem de öğrenci başarısı açısından başarılı sonuçlar elde edilmiştir (Akkuş, Günel, \& Hand, 
2007; Chanlen, 2013; Choi, Greenbowe, \& Hand, 2013; Çıkmaz, 2014; Demirbağ \& Günel, 2014; Greenbowe \& Burke, 2008; Günel, Memiş \& Büyükkasap, 2010; Hand \& Choi, 2010; Kıngır, Geban \& Günel, 2012; Nam, Choi, \& Hand, 2011; Yeşildă̆-Hasançebi \& Günel, 2013). ATBÖ yaklaşımı, 1999 yılında Brian Hand ve Carolyn Keys tarafından geliştirilmiş ve yaklaşımı geliştirmek ve daha iyi açıklamak için çalışmalar hala devam etmektedir. ATBÖ yaklaşımı öğrencilerin dil pratiklerini (konuşma, dinleme, okuma ve yazma) vurgulayarak, argümantasyon tabanlı araştırma-sorgulamay1 destekleyerek öğrencilere daha zengin öğrenme ortamı sunmaktadır. ATBÖ yaklaşımı, öğretmen ve öğrencilere yönelik dersin işlenmesini çerçeveleyen iki şablon sunmaktadır (Tablo 1). Öğretmen şablonu dersin neleri içermesi yönünden rehberlik ederken, öğrenci şablonu ise öğrencilere yazı ve argümantasyonlarında bir çerçeve çizmektedir. ATBÖ yaklaşımında, argümantasyon bilimsel argümanın üç bileşeni olan soru-iddia-kanıt üzerine inşa edilirken, Hand ve arkadaşları $(2017,2018)$, ATBÖ yaklaşımının (1) temel epistemik çerçeve gelişimi, (2) argümantasyon ve (3) özet yazımı olmak üzere üç fazdan oluştuğunu belirtmiştir.

Tablo 1. ATBÖ öğrenci ve öğretmen şablonları

\begin{tabular}{|c|c|}
\hline Öğrenci Şablonu & Öğretmen Şablonu \\
\hline $\begin{array}{l}\text { 1. Başlangıç Soruları-Sorularım } \\
\text { nelerdir? }\end{array}$ & $\begin{array}{l}\text { 1. Bireysel ya da grup kavram haritası yaparak ön bilgileri ortaya } \\
\text { çıarma }\end{array}$ \\
\hline 2. Testler- Ne yaparım? & $\begin{array}{l}\text { 2. İnformal yazma, açıklamalar yapma, beyin firtınası ve soru } \\
\text { sormayı içeren ön laboratuar aktivitesi }\end{array}$ \\
\hline 3. Gözlemler- Ne gördüm? & 3. Laboratuvar aktivitesine katılma \\
\hline 4. İddialar- Ne iddia edebilirim? & $\begin{array}{l}\text { 4. Görüşme I-Laboratuvar aktivitesi için kişisel yazma aktivitesi } \\
\text { yapma (Örneğin; makale yazma) }\end{array}$ \\
\hline $\begin{array}{l}\text { 5. Kanit- Nasıl bilebilirim? Neden bu tür } \\
\text { iddialarda bulunuyorum? }\end{array}$ & $\begin{array}{l}\text { 5. Görüşme II- Küçük gruplardaki veri yorumlarını paylaşma ve } \\
\text { kıyaslama (Örneğin; grup kartları yapma) }\end{array}$ \\
\hline $\begin{array}{l}\text { 6. Okuma/karşılaştırma- Fikirlerim diğer } \\
\text { fikirlerle nasıl kıyaslanabilir? }\end{array}$ & $\begin{array}{l}\text { 6. Görüşme III- Kitap ya da diğer kaynaklar ile karşılaştırma } \\
\text { (Örneğin; odaklanan soruları cevaplamada grup notlarını } \\
\text { yazma) }\end{array}$ \\
\hline \multirow[t]{2}{*}{ 7. Yansıtma- Fikirlerim nasıl değişti? } & $\begin{array}{l}\text { 7. Görüşme IV- Bireysel yansıma ve yazma (Örneğin; büyük } \\
\text { dinleyiciler için rapor ya da poster gibi sunumlar yaratma) }\end{array}$ \\
\hline & 8. Kavram haritası yapmada son bilgileri ortaya çıkarma \\
\hline
\end{tabular}

\subsubsection{Temel epistemik çerçeve gelişim fazı}

Birinci faz olan epistemik çerçeve gelişimi için (a) her bir ünitenin öğrenilmesi gereken "ana fikir"lerden oluştuğunun (b) dil ve dil unsurlarının öğrenmedeki rolünün ve (c) öğrenmenin bir müzakere süreci olduğunun anlaşılması gerektiğini belirtmektedir. Bunların yanında öğrenmede, alan ön bilgisinin ortaya çıkarılmasının gerekliliğinin, argümantasyon yapısı ve pratiğinin ve grup çalışmasının rolünün anlaşılması da vurgulanmaktadır. Burada dikkat edilmesi gereken husus birinci fazı, üç aşamalı bir sistemin ilk adımı olarak düşünmek yerine, diğer fazlarla birlikte gelişeceği gerçeğidir. Yani, Cavagnetto'un (2010) çerçevesini çizdiği kültürlenme-odaklı yaklaşımların karakteristik özelliği olarak, bu faz, uygulama esnasında doğal ortamında yaşayarak anlamlı epistemik anlayış gelişecektir.

\subsubsection{Argüman fazı}

İkinci faz olan argümantasyon fazı ise, asıl bilimsel kavramları öğrenmenin gerçekleştiği, öğrenme ve öğretmeye temel teşkil eden araştırma-sorgulamanın yapıldığı yerdir. Öğrencilerin bu aşamada kendi soru-iddia-kanıtlarını oluşturarak bir argüman oluşturmaları ATBÖ yaklaşımının önemli bir gereksinimidir. Burada vurgulanması gereken husus, bireysel ve grup tartışmalarının argüman gelişiminde hayati bir öneme sahip olduğudur. ATBÖ yaklaşımında argüman soru, iddia ve kanıt üçlüsüne dayanmakla beraber bu bileşenlerin herbirinin kendi içerisinde akıl yürütmelerle desteklenmesi gerekir. Argüman, muhatabını belirli bir öncülün (soru, dizayn vb.) değeri hakkında ikna etmektir. Bu fazda, argümanın temel yapısı öncül-gerekçelendirme-çıkarım üçlüsüne dayanmaktadır. ATBÖ yaklaşımı, bütün fen bilimlerinin üzerinde anlaşmazlık olan bir soruyla başladığını savunan 
Haack'in (2004) önerdiği gibi bir soruyla başlamaktadır. Sınıf ya da grup tartışmaları, oluşturulan soruları doğrulamak için gereklidir. Kullanılacak sorunun belirlenmesi için soruların doğrulanması ve sorular üzerinde bir anlaşmaya varılması gerekir. Sorudan sonra, soruyu cevaplamak için oluşturulan her bir dizayn için de öncül-gerekçelendirme-çıkarım şeklinde akıl yürütmelerin yapılması istenerek bireyin sadece bilimsel içeriği değil bilimsel pratikleri de özümsemesi sağlanır. Bu çok katmanlı tartışma süreci öğrencilere çalıştıkları konuyu yapılandırmaları ve kritik etmeleri adına önemli bir fırsat sunmaktadir.

Burada, sınıf ortamında kullanılmasının uygunluğu tartışılan Toulmin'in argümantasyon yapısından ziyade Walton'un argümantasyon yapısı benimsenmektedir (Hand, 2008). Walton (2016), argümantasyon için bilgi, kanıt ve argüman arasındaki ilişkiye dayanan 5 basamak önermektedir: (1) kanıtlanması gereken nihai sonuç, (2) sonuç çıkarılacak veri, (3) bilgiyi önerme olarak sınıflandırmak için veriyi düzenleme ve buradan iddia ile ilgili sonuca varma, (4) kanıta ulaşabilmek için bir dizi gerekçelendirme yapılması ve (5) gerekçelendirmeler zincirinin nihai sonucu kanıtlaması. Burada, bilgi önermesinin (iddia) oluşturulabilmesi için veri ve gerekçelendirmenin toplamının kanıtı oluşturduğu dikkate alınmalıdır. Diğer bir ifadeyle, gerekçelendirme olmadan kanıttan bahsedemeyiz. Öğrenci iddia ve kanıtlarını oluşturma sürecinde, kanıtlarını değerlendirebilmek ve test etmek amacıyla, öncelikle sınıf arkadaşları ile grup ya da sınıf tartışması esnasında birbirlerini kritik eder. Sonrasında ise bilimsel yazılı kaynaklarla (bilimsel normlarla) tartışma sonucu "harici değerlendirmelerini (sınıfta gerçekleşen değerlendirmenin haricinde yapılan değerlendirme)" tamamlar. Böylelikle, öğrenciler daha güçlü ve savunulabilir bir iddia ile bu iddiasını destekleyecek kanıtlar oluşturur. Aynı zamanda gündelik dili yoğun bir şekilde kullandıkları grup tartışmalarından, harici değerlendirme ile birlikte bilimsel dile doğru evrileceklerdir. Sonuç olarak, argüman fazı, başlangıç sorusuyla başlayan, kanıt üretimi ve nihai iddia ile sonuçlanan yoğun diyalog içeren bireysel ve sosyal bir tartışma süreci olarak gerçekleşir. ATBÖ yaklaşımı ayrıca, "fikirlerim nasıl değişti?" sorusunu yanıtlatarak, öğrencilerin süreç boyunca fikirlerinde meydana gelen değişiklikleri de yansıtmalarını istemektedir. Bu sürecin son ürünü ise yine "öğrenmek için yazma" aktivitesi olan yazılı argümantasyondur. Diğer bir deyişle, öğrenciler sözel argümantasyon sürecinden yazılı argümanları geliştirme sürecine geçmektedir. Yazılı argüman oluşturma süreci, sözel argümantasyonun doğaçlama karakterine karşılık, daha sistematik ve daha doğrusal bir biçimde argümanın ifade edilmesini içermektedir (Şekil 1).

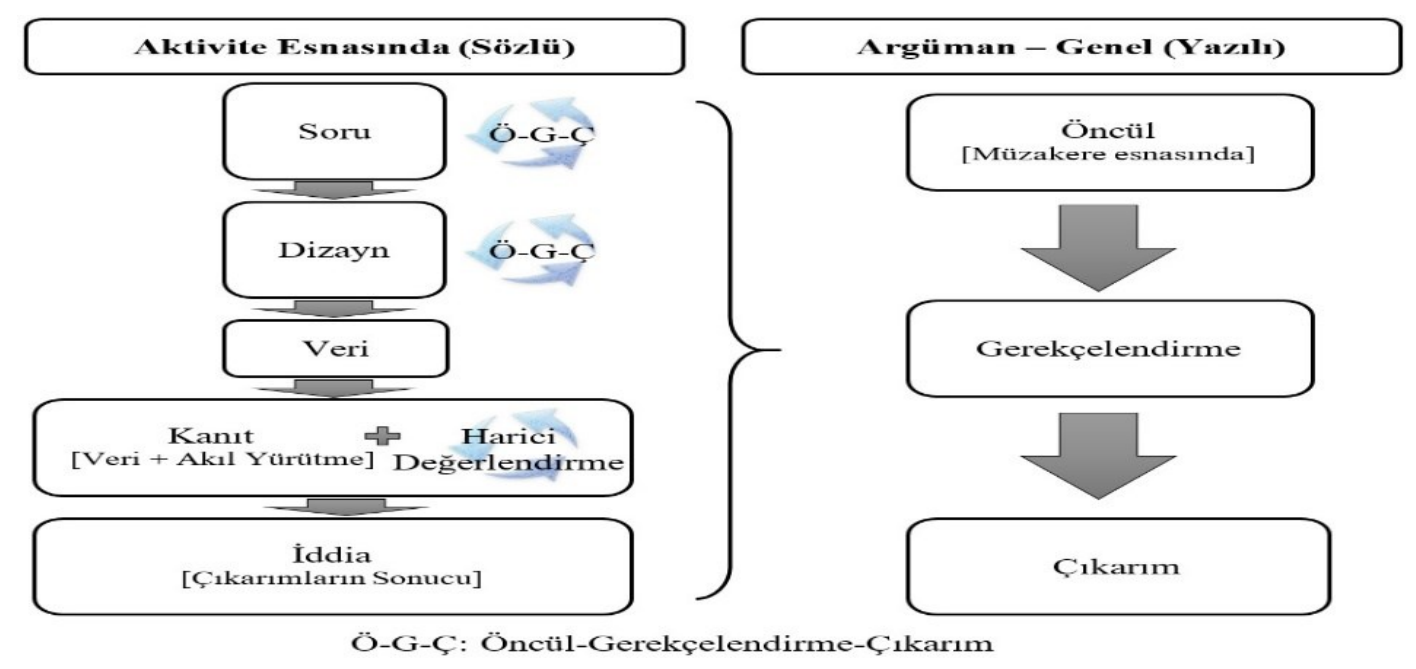

Şekil 1. ATBÖ yaklaşımının yazılı ve sözlü argümanlarının oluşması

\subsection{3. Özet yazım fazı}

Son faz olan özet yazımı ise yine bir "öğrenmek için yazma" şeklinde adlandırılan bir aktivite olup bireyin ünite boyunca öğrendiğgi "ana fikir"leri kendisinden daha genç ya da o konuyu bilmeyen başka birisine anlatmasıdır. Özet yazma etkinliklerinde öğrenciler, öğretmenden farklı bir muhataba yazmaktadır. Bu durum, bir dizi kavram ve dil transferi gerektirmektedir. Hand (2008), öğrencilerin bu çeşit yazma etkinliklerini tamamladıklarında günlük dil, fen dili ve muhatabın dili olmak üzere üç farklı dil arasında birden fazla transfer süreci geçirdiklerini belirtmiştir. Bu bağlamda, öğrenciler fen dilini 
kendilerinin anlayabileceği günlük dile çevirmektedir. Sonrasında bu dili muhataplarının anlayabilmesine olanak sağlamak ve açılamak amacıyla muhatabın diline çevirirler. Bu çeviri süreçleri, öğrencinin içerik bilgisiyle meşgul olmasını, yazmalarını istenilen dil öğeleriyle çervelendirmelerini ve muhatablarını gözönünde bulundurarak yazılı söylemlerini sergilemelerini gerektirmektedir. Böylece öğrenciler, üzerinde çalıştıkları konu hakkında daha kapsamlı ve zengin bilgiler yapılandırmaktadır (Hand, Norton-Meier \& Jang, 2017; Hand, Shelley, Laugerman, Fostvedt \& Therrien, 2018).

\section{5 АТВÖ Yaklaşımı ve Öğretmen Değişimi}

Argümantasyon tabanlı araştırma sorgulama yönteminin fen (bilim) öğreniminde önemi yenilenen öğretim programlanında vurgulanmasına rağmen fen sınıflarında yeterince yer bulamadığı, yer bulduğunda ise istenen kalitede olmadığı görülmektedir (Driver, Newton \& Osborne, 2000). Bunun önünde ise en büyük engelin sınıf ortamını düzenleyen ve yaklaşımların uygulayıcıları olan öğretmenlerin, hem öğrencilik yıllarında hem de öğretmen yetiştirme programlarında argümantasyon tabanlı araştırma sorgulama temelli öğrenme tecrübelerinin olmaması ya da yaklaşım hakkında yeterince mesleki gelişim desteği alamamalarıdır (Abd-El-Khalick ve diğerleri, 2004; Hahn \& Gilmer, 2000). Bu bağlamda, fen öğretmenlerinin sınıflarında başarılı uygulamalar yapabilmeleri için, fen öğretmeni yetiştirme programları ve mesleki gelişim seminerleri, öğretmen adaylarının argümantasyon tabanlı araştırma sorgulama ortamlarını tecrübe etmesine, bu yaklaşımı öğrenmelerine yapmış olduğu katkıyı deneyimleyerek farketmelerine olanak sağlayacak şekilde tasarlanmalıdır (Abd-El-Khalick ve diğerleri, 2004). Bu çalışma kapsamında kullanılan örnekler fen bilgisi öğretmen adaylarına aittir. Bu bağlamda, öğretmen adaylarının deneyimleyerek yapmış oldukları öğrenmelerinin, ileri yıllarda öğretmenlik yaptıkları sınıflarda öğrencilerine bu yaklaşımı başarılı şekilde uygulamaları için ilk adım olacağı düşünülmektedir; çünkü yapılan araştırmalar öğretmenlerin bilimsel pratikleri yaşantılaması ile mesleki gelişimleri arasında pozitif bir ilişki olduğunu göstermiştir (Rogan \& Aldous, 2005).

\section{ÇALIŞMANIN AMACI}

Farklı sınıf seviyelerinde başarılı sonuçlar veren ATBÖ yaklaşımını etkili bir şekilde uygulamak isteyen öğretmenlere ve öğretmen adaylarını yetiştiren akademisyenlere, ATBÖ'nun, uygulandığı sınıf ortamlarından örnekler ile sunulması bir ihtiyaç olarak ortaya çıkmaktadır (Burke, Greenbowe \& Hand, 2005; Burke, Hand, Poock \& Greenbowe, 2005). Bu bağlamda, bu çalışmanın amacı ATBÖ yaklaşımının, ağılıklı olarak argüman fazının, gerçek sınıf ortamında nasıl gerçekleştiğini örnek uygulama ile sunmaktır. Bu amaç doğrultusunda, (1) ATBÖ’ye genel girişin nasıl yapılabileceği, (2) öğrencilerin laboratuvara gelmeden önce, (3) geldikten sonra; soru oluşturma, deney tasarlama, iddia ve kanıt oluşturma (4) laboratuvar sonrasında yapılan uygulamalar yazılı ve sözlü örnekler ile sunulacaktır.

Burada sunulacak örnekler, İç Anadolu bölgesinde yer alan bir üniversitenin birinci sınıfında öğrenim gören fen bilgisi öğretmen adaylarının genel kimya laboratuvar dersinden elde edilen görüntü kayıtlarının ve laboratuvar raporlarının incelenmesi ile elde edilmiştir. Bu çalışmanın öncelikli olarak ATBÖ’yü lisans düzeyinde uygulamak isteyenler için bir fikir vermesi açısından önemli olduğu düşünülmektedir.

\section{ATBÖ'YE GİRIŞ}

Öğrenciler, АTBÖ’ye başlarken, dönem başında, yöntemin öğrenci şablonu (Tablo 1) ile ilgili bilgiler almaktadır. Bu aşamada, iyi bir başlangıç sorusu nedir, nasıl olmalıdır, iddia ve kanıt nedir, iddia ve kanıt yazılırken nelere dikkat edilmelidir gibi sorular sınıfça tartışııı, öğrencinin zihninde canlanması için argüman bileşenleri olan soru-iddia-kanıt üçlüsü somut örnekler ile desteklenir. Sonrasında, Soru-İddia-Kanıt üçlüsüne uygulama zemini olarak, alan bilgisi gerektirmeyen "Gizemli Etkinlik" benzeri bir aktivite yapılabilir (bknz. Burke ve diğerleri, 2005; Kıngır, 2011) Ayrıca, öğrencilerden her etkinlikten önce ve etkinlik bittikten sonra kavram haritası oluşturmaları isteneceği için, dönemin başında öğrencilere, kavram haritasının nasıl oluşturulacağı, kavram haritasının bileşenleri (kavram, örnek, önerme, çapraz bağlantı vs.), kavram haritası çeşitleri (hiyerarşik, ağ, zincir) hakkında bilgi verilir ve örnek etkinlikler yapılır (bknz. Kaya, 2003). Bundan sonraki kısımda, ATBÖ yaklaşımının laboratuvar öncesinde, esnasında ve sonrasında neler içerdiği ve nasıl gerçekleştiği kimyasal denge konusunda yazılı ve sözlü örnekler ile sunulacaktır. 


\section{1. АТВÖ Laboratuvar Öncesi Uygulamaları Nasıldır?}

Öğrenciler laboratuvara gelmeden önce föylerindeki etkinlik ile ilgili verilerden yola çıkarak bireysel başlangıç sorularını belirlerler. Sorularını, yöntemlerini ve yapılacak deneylerle ilgili hangi güvenlik önlemlerini alacaklarını yazarlar. Ayrıca, öğrenciler laboratuvara gelmeden önce konuyla ilgili ön kavram haritalarını çıkartırlar. Buna örnek olarak, kimyasal denge konusunda bir öğrencinin hazırladığı ön kavram haritası Şekil 2'de gösterilmiştir. Burada öğrenci kimyasal dengeyi merkeze alıp (ă̆ kavram haritası) bu kavramdan 8 bağlantı yapmıştır. Aynı öğrencinin bireysel başlangıç soruları şu şekildedir: "Derişim denge tepkimesini nasıl etkiler?" ve "Sıcaklık denge tepkimesini nasıl etkiler?". $\mathrm{Bu}$ sorular sıcaklık ve derişim değişkenlerinin denge tepkimesini nasıl etkilediğinin incelenmesine yöneliktir. Burada öğrenci, bu deneyle ilgili alacağı önlemleri şu şekilde ifade etmiştir: "çözeltilerin cilde temasına dikkat edilmelidir, asitler zararlıdır çok fazla koklanmamalıdır, camlar kırık olabilir dikkatli kullanılmalıdır, stok çözeltiye spatül konulmaz".

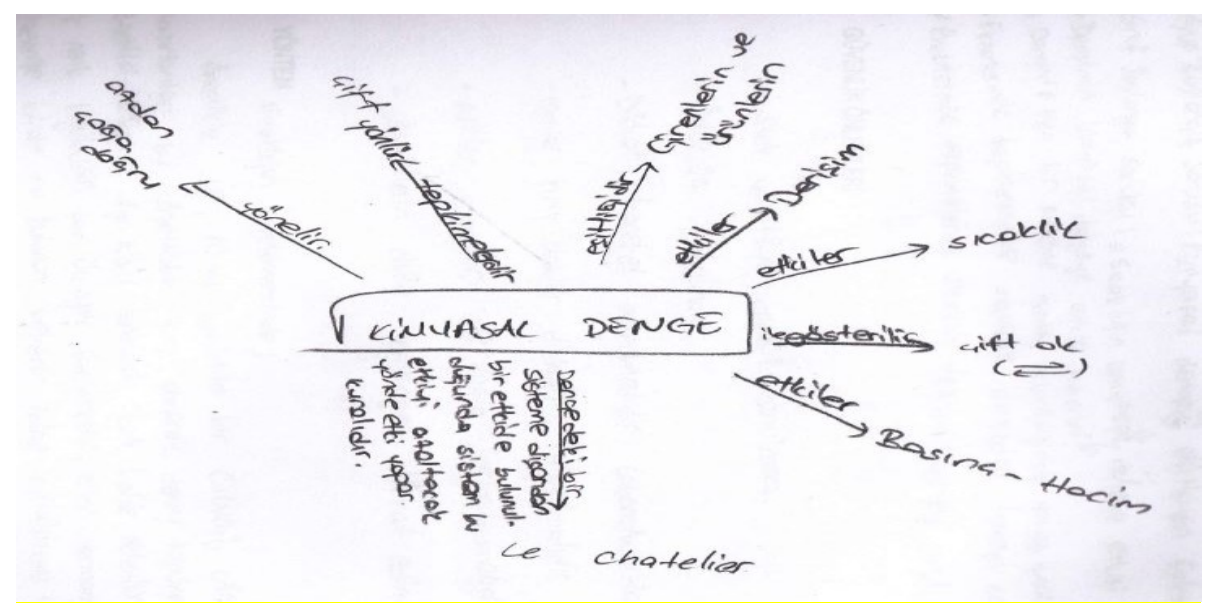

Şekil 2. Öğrenci ön kavram haritası örnĕgi

\section{2. АТBÖ Laboratuvar Esnası Uygulamaları Nasıldır?}

Bireysel başlangıç sorularını hazırlayarak laboratuvara gelen öğrenciler, gruplarındaki arkadaşları ile tartışarak grup başlangıç sorularına karar verirler. Her grup, belirledikleri başlangıç sorularını tahtaya yazar. Tahtaya yazılan grup başlangıç soruları öğretmen rehberliğinde, sınıfça tartışılarak, tüm sınıfın çalışacağı sınıf başlangıç soruları belirlenir. Böylece her bireyin kendi ön bilgilerine dayanarak oluşturduğu bireysel başlangıç soruları, konu üzerine yoğun tartışmaların yaşandığı ve sürekli olarak gerekçelendirme ve çıkarımlar yapılarak sınıfça başlangıç sorusuna dönüşürken, öğrencinin soruyu ve daha sonrasındaki süreçleri sahiplenmesi sağlanır. Öğrencilerin, bu karar sürecinde seçme özgürlügüne sahip olmaları etkinliklere katılımını ve motivasyonlarını artırır.

Başlangıç soruları belirledikten sonra, belirlenen sorulara cevap bulabilmek için yöntem tartışılır. Yöntem kısmına karar verildikten sonra, öğrenciler gruplarında görev dağılımı yaparlar ve verilerini toplarlar. Bazen diğer gruplarla aralarında görev dağılımı yaparak hangi grubun ne tür veri toplamada görevli olduğu belirlenir. Öğrenciler topladıkları verileri yorumlayarak iddia ve kanıtlarını oluşturur. Sonrasında topladıkları verileri tahtaya yazarak sınıf tablosu oluştururlar. Bu tablodan yola çıkarak iddia ve kanıtlarını tartışırlar. Bu aşamada, öğretmen sorduğu sorularla öğrencilere rehberlik eder. Böylece, öğrenciler iddia ve kanıtlarına, grupça ve sınıfça tartışarak nihai kararı vermiş olarak laboratuvar etkinliğini bitirmiş olurlar.

ATBÖ yaklaşımında, başlangıç sorularının belirlenmesi, yöntemin kararlaştırılması ve iddiakanıtların oluşturulması esnasında gerçekleşen diyaloglarda öğrenciler doğal olarak sürekli önermegerekçelendirme-çıkarım (Ö-G-Ç) döngüsü içerisinde akıl yürütmelerde bulunur. Bu aşamalarda öğretmenin rolü öğrenci diyaloglarını tıkandığı ya da büyük fikrin dışına doğru yönelindiği noktalarda, sorularla ya da küçük işaretlerle öğrencilerin önünü açmak olmalıdır. Bunun için, ögrencilerden gelen soruları ve fikirleri farklı kelimelerle tekrarlayarak vurgulayabilir. Böylelikle öğrenciler daha önceden ifade etmiş oldukları fikirleri yeniden duyduklarında bu fikirleri gözden geçirebilir ve yeni fikirler ileri sürebilirler. 


\subsubsection{Başlangıç soruları}

Başlangıç soruları, genel olarak, bir deney yapılarak cevaplandırılacak nitelikte olmalıdır. $\mathrm{Bu}$ bağlamda, başlangıç soruları araştırılabilir olmalı ve bağımlı bağımsız değişkenleri içerecek şekilde hazırlanmalıdır. Yöntemle ilgili olan, cevabı evet-hayır olan sorular, birden fazla değişkeni aynı anda incelemeye çalışan sorular verimli sorular değillerdir. Tablo 2'de, verimli ve verimli olmayan başlangıç soruları karşılaştırılmıştır.

Tablo 2. Verimli ve verimsiz başlangıç sorularının incelenmesi

\begin{tabular}{|c|c|}
\hline Verimsiz başlangıç soruları & Verimli başlangıç soruları \\
\hline Kimyasal dengeye etki eden faktörler nelerdir? & $\begin{array}{l}\text { Derişim kimyasal dengeye nasıl etki eder? } \\
\text { Dengede olan bir sistemde ürünler tarafına madde } \\
\text { eklenmesi dengeyi nasıl etkiler? } \\
\text { Dengede olan bir sistemde girenler tarafına madde } \\
\text { eklenmesi dengeyi nasıl etkiler? } \\
\text { Dengede olan bir sistemden madde azaltılması } \\
\text { (girenler ya da ürünler tarafından) dengeyi nasıl } \\
\text { etkiler? }\end{array}$ \\
\hline Sicaklığın kimyasal dengeye etkisi var mıdır? & $\begin{array}{l}\text { Sicaklık değişimi ekzotermik tepkimelerde kimyasal } \\
\text { dengeyi nasıl etkiler? } \\
\text { İleri yönde endotermik olan tepkimelerde sıcaklık } \\
\text { artışı kimyasal dengeyi nasıl etkiler? }\end{array}$ \\
\hline $\begin{array}{l}\text { Deney niçin bir deney tüpü içerisinde gerçekleştiliyor } \\
\text { da bir beher de gerçekleştirilmiyor? } \\
\text { Deneyde neden balonjoje kullanılmaktadır? }\end{array}$ & $\begin{array}{l}\text { Basınç ile kimyasal denge arasında nasıl bir ilişki } \\
\text { vardır? } \\
\text { Katalizör ile kimyasal denge arasında nasıl bir ilişki } \\
\text { vardır? }\end{array}$ \\
\hline
\end{tabular}

Şekil 3'teki örnekte öğrencinin grup başlangıç sorusu "kimyasal dengeyi etkileyen faktörler nelerdir? Nasıl etkilerler?" şeklindedir. Bireysel ve grup soruları kıyaslandığında, öğrencinin bireysel sorularında sıcaklık ve derişimden ayrı ayrı bahsederken, grup başlangıç sorusunda dengeyi etkileyen faktörler üzerine odaklandığı görülmektedir ki bu faktörler sıcaklık ve derişimi içermektedir. Grup ve sınıf tartışmaları sonrasında başlangıç soruları daha verimli bir hal almıştır. Grup sorularının sınıfça tartışılarak, deneye rehberlik edecek başlangıç sorularına karar verilmesi süreci aşağıdaki örnek diyaloglar ile daha açık görülecektir.

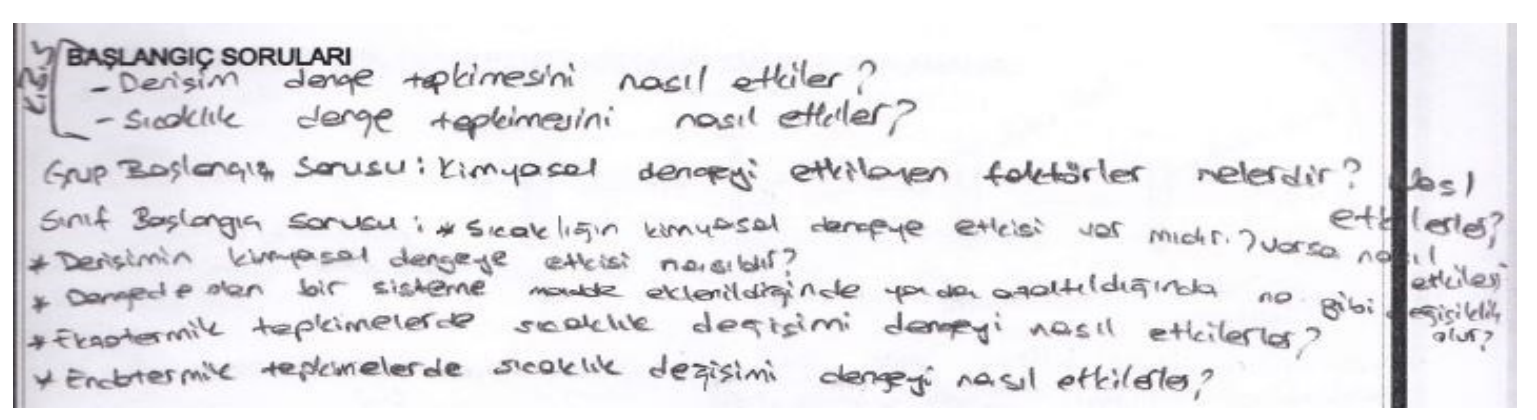

Şekil 3. Öğrencinin grup ve sınıf başlangıç soruları

Altı grubun bulunduğu sınıfta her bir grup sınıfça ortak bir başlangıç sorusu oluşturmak için elde ettiği soruları tahtaya yazarak üzerinde tartışmaya başlar. Grup başlangıç soruları şu şekildedir:

Grup 1: Denge halindeki bir tepkimeye dlşarıdan bir madde eklendiğinde denge tepkimesi bozunur mu?

Grup 2: Kimyasal dengeye sicaklı̆̆ın etkisi nasil olur?

Grup 3: Kimyasal dengeyi etkileyen faktörler nelerdir? Nasll etkilerler?

Grup 4: Madde eklenmesi dengeyi nasll etkiler?

Grup 5: Sicaklı̆̆ın kimyasal dengeye etkisi var mıdır? Varsa nasll etkisi vardır?

Grup 6: Bir tepkimenin dengede olduğunu nasll anlarız? Dengeyi etkileyen faktörler nelerdir? 
Tahtadaki sorular öğretmen rehberliğinde tartıșılmaya başlanır. Burada üzerinde durulması gereken konu, öğretmenin bilgi kaynağı olmaktan ziyade öğrencinin kendi bilgilerinden yola çıkarak kendi sorusunu elde etmesini sağlayan bir rehber olduğunun farkedilmesidir. Soruya karar verenin öğretmen değil öğrenci olması, bilginin öğrenci tarafinda sahiplenilmesini sağlar. Şekil 3 'te görülen sınıf başlangıç sorularının oluşturulmasını sağlayan örnek diyalog şu şekilde gerçekleşmiştir (Ö: Öğretmeni Ö1, Ö2, Ö3 vs ise öğrencileri simgelemektedir):

Ö: $\quad$ Hangi soru ya da sorular araştırlabilir?

Ö1: $\quad$ (grup 5) Sıcaklı̆̆ın kimyasal tepkimeye etkisi var mıdır? Varsa nasıl etkisi vardır?

Ö: $\quad$ Başka araştırılabilir soru var mı?

Ö2: $\quad$ (grup 3) En genel soru olarak "Kimyasal dengeyi etkileyen faktörler nelerdir? Nasıl etkilerler?"

Ö: $\quad$ Bu soruyu araştırabilir miyiz?

Ögrenciler: Hayır (Dĭger grup ögrencileri)

Ö: $\quad$ Niye araştıramıyoruz? Gerekçeniz nedir? (Gerekçelendirme yapılması isteniyor.)

Ö3: $\quad$ Faktörlerin ne olduğunu bilmiyoruz.

Ö: $\quad$ (tüm sınıfa) Ne yapabiliriz bunun için?

Ö4: $\quad$ Sicaklı̆̆ın kimyasal dengeye etkisi nasıldır? Başka bir gruptan (grup 2) kimyasal dengeye derişimin etkisi nasıl olur?

Ö: $\quad$ Bu deneyde en genelde neyi araştırmaya çalışıyorsunuz?

Ö5: $\quad$ Kimyasal dengeye etki eden faktörleri.

Ö: $\quad$ Kimyasal dengeye etki eden faktörleri öyle mi?

Ögrenciler: Evet.

Ö: $\quad$ Peki bunlardan hangilerini araştıracaksınız?

Öğrenciler: Sicaklık ve derişim.

Ö: $\quad$ Bă̆ımlı bă̆ımsız değişken kapsamında düşündüğ̈̈nüzde bă̆ımsız değişkeniniz nedir?

Öğrenciler: Sicaklık bă̆ımsız, derişim bă̆ımsız.

Ö: $\quad$ Peki nasil inceleyebilirsiniz? Ne tip sorular sorabilirsiniz?

Ö6: $\quad$ Sicaklı̆̆ın kimyasal dengeye herhangi bir etkisi var mıdır? Varsa nasıl bir etkisi vardır?

Ö7: $\quad$ Derişimin kimyasal dengeye etkisi nasıldır? Dengede olan bir sisteme madde eklendiğinde ya da azaltıldı̆̆ında ne gibi değişiklikler olur?

Ö: $\quad$ Peki ikinci değişkenimiz ne idi?

Öğrenciler: Sicaklık.

Ö: $\quad$ Sicaklık için ne diyebilirsiniz?

Öğrenciler: Endotermik ve ekzotermik. Mesela endotermik tepkimeye ısı verdiğimizde nasıl olur?

Ö: $\quad$ Peki onu soru şeklinde nasıl ifade edebilirsin? Hangisi isı allyor hangisi isı veriyor idi?

Ö8: $\quad$ Isl alan endotermik, isl veren ekzotermik.

Ö: $\quad$ Peki siz bu tür tepkimlerde sicaklı̆̆ın etkisini araştırabilir misiniz?

Ö9: $\quad$... $\quad$ isi alan ve isi veren...

Ö: $\quad$ Peki soru olarak nasl ifade edebilirsiniz, isl alan ve isl veren tepkimelerle ilgili soruyu?

Ö10: $\quad$ Endotermik bir tepkimeye isl verdiğimizde denge nasll olur? Ya da ekzotermik bir tepkimeye isl verdiğimizde denge nasil olur?

Ö: $\quad$ Bunu nasıl daha genel bir şekilde ifade edebiliriz?

Ö10: $\quad$ Endotermik ve ekzotermik tepkimeler dengeyi nasll etkiler?

Ö: $\quad$ Bunlarl ayrı ayr yazdı̆̆ımızda nasıl olur?

Ö10: $\quad$ Endotermik tepkimeler nasıl etki eder? Ekzotermik tepkimeler nasıl etki eder?

Ö: $\quad$ Düzgün bir şekilde ifade edelim.

Ö10: $\quad$ Endotermik tepkimelerde sicaklık dengeyi nasll etkiler?

Ö: $\quad$ (tüm sınıfa sorarak) Mantıklı geliyor mu arkadaşınızın dediği şey?

Ögrenciler: Evet. 
Öğretmen en sonunda öğrencilerin vardıkları son kararı tekrar ederek söylenenleri toplarlar. Burada öne çıkan husus öğretmenden öğrenciye doğru sürekli soru yöneltilmesi ve öğrencilerin verimli sorulara ulaşmalarıdır. Bu uygulamanın bir adım ötesi, gerçekleşen diyaloğun tamamen öğrencilerin arasında meydana gelmesi için firsat tanımak olabilir. Bu ise zamanla öğrencilerin tecrübelenerek verimli soruyu elde etmelerinin etkinlik için önemini kavramaları ile gerçekleşecektir. Başlangıç sorularına karar verdikten sonra, bu sorulara cevap verecek yöntemin belirlenmesi gerekir.

\subsubsection{Yöntem oluşturulması}

Başlangıç sorularına cevap verebilecek birkaç yöntem laboratuvar föylerinde öğrencilere öneri olarak verilmiştir. Burada amaç, öğrencilerin araştırma sorgulama uygulamalarında kendilerini çaresiz hissetmelerini engellemektir. Öğrenciler, föylerindeki ipuçlarından yola çıkarak laboratuvarda mevcut bulunan malzemeler ile sorularını cevaplayacak verileri toplamak üzere deney düzeneklerini oluştururlar. Başlangıç sorusunda olduğu gibi yöntemin de başlangıç sorusunu cevaplamak için yeterli ve uygun olup olmadığı sınıfça tartışılarak geliştirilir. Burada da yine her öneri sorgulanmakta, gerekçelendirilmekte ve nihayetinde uygun yöntem çıkarım yapılarak oluşturulmaktadır. Yöntem tartışılırken öğrenciler oluşturdukları çizimleri ve çoklu gösterimleri kullanarak argümanlarını güçlendirebilir. Öğrencilerin tartışmalarda kullandıkları bazı bilgiler (örneğin, formüller, denklemler vs) onlara öneri olarak verilen yöntemde bulunmamaktadır. Yönteme karar verilmesi ve ardından yöntemin uygulanmasına yönelik gerçekleşenler ve diyaloglar aşağı $d a$ gösterilmiştir.

Öğrenciler, sıcaklığın dengeye etkisi ile ilgili soruda, $\mathrm{Cu}\left(\mathrm{NO}_{3}\right)_{2}$ ve $\mathrm{NaCl}$ ile; derişimin dengeye etkisini incelemek için $\mathrm{K}_{2} \mathrm{Cr}_{2} \mathrm{O}_{7}$ ve $\mathrm{K}_{2} \mathrm{CrO}_{4}$ çözeltilerinin hazırlanması gerektiğini tartışırken, kullanılacak düzenekle ilgili gösterimleri tahtaya çizerler. Hazırlanacak çözeltilerin ne kadar olması gerektiği konusunda tartışmalarda bulunurlar. Çözeltilerin hazırlanmasıyla ilgili kimyasal formüllerden, muhtemel reaksiyon denklemlerinin ne olması gerektiği konusunda tartışır ve uzlaşmaya varırlar. Öğretmen bu aşamada, öğrencilere yönlendirici sorular sorarak onların fikirlerini derinlemesine ortaya çıkarmaya çalışır. Yapılan tartışma sonucunda sınıfça uzlaşmaya varılmaya çalış1lır. Bu aşamada, öğrenci ve öğretmen diyaloğu şu şekilde gerçekleşmiştir:
$\ddot{O}:$
Ilk sorunuza cevap bulabilmek için nasıl bir yöntem önerirsiniz? Kim yöntem önerecek derişim ile ilgili olarak?
Ö11: $\quad$ Tahtaya 3 deney tüpü çizer. Birincisine ve üçüncüsüne $\mathrm{K}_{2} \mathrm{CrO}_{4}$ koyar. İkincisine $\mathrm{K}_{2} \mathrm{Cr}_{2} \mathrm{O}_{7}$ koyar. Molaritenin formülünü yazar. $M=n / V$ (Öğrencilere örnek verilen yöntemde formül yer almamaktadir.)
Ö: $\quad$ Ne yapmaya çallşlyorsunuz burada?
Ö11: $\quad$ Belli bir miktar çözelti hazırlamaya çalışıyoruz.

Sonrasında, sınıftaki diğer öğrenciler de tartı̧̧maya katılır ve öğrenciler 0,2 M 20 mL çözelti hazırlamak isterler. İlk önce, çözeltilerin $10 \mathrm{~mL}$ olmasını, sonrasında ise deneyde bir sıkıntı olursa tekrar tekrar çözelti hazırlamamak için $10 \mathrm{~mL}$ 'nin çok az olduğunu düşünürler ve çözeltinin $20 \mathrm{~mL}$ olmasına karar verirler. Daha sonra, çözelti hazırlamak için maddenin gramlarının hesaplanması gerektiğinden bahsederler. Burada, öğrenciler $M=n / V$ formülünü tahtaya yazarak, $n=m / M A$ formülünü $\mathrm{m}=\mathrm{nXMA}$ şekline dönüştürerek kütlenin hesaplanması gerektiğinden bahsederler. Öğrenciler hazırlanan $20 \mathrm{~mL}$ lik çözeltiden $5 \mathrm{~mL}$ alınarak 1. ve 3. deney tüplerine koyulması gerektiğini, sonrasında ise $\mathrm{HCl}$ çözeltisi konulması gerektiğinden bahsederler. Bu sırada, sınıftaki öğrencilerden 1. ve 2. deney tüplerine ya da 1. ve 3. deney tüplerine konulması hususunda farklı cevaplar gelir. Nihayetinde, öğrenciler 1. ve 3. deney tüplerine $\mathrm{HCl}$ konması gerektiğinde anlaşırlar. Bu aşamada tartışılan bilgiler öğrencilere föylerinde öneri olarak verilen yöntemde bulunmamaktadır. Öğretmen bu aşamada öğrencilere burada maddeleri neye getirmeye çalıştıklarını sorar. Öğrenciler dengeye getirmeye çalıştıklarını, 1. ve 2. deney tüplerindeki çözeltilerin kontrol çözeltileri olduğundan bahsederler. $\mathrm{Bu}$ aşamada öğretmen, $\mathrm{K}_{2} \mathrm{Cr}_{2} \mathrm{O}_{7}$ ve $\mathrm{K}_{2} \mathrm{CrO}_{4}$ çözeltilerinin nasıl maddeler olduğunu sorar. Öğrenciler, laboratuvardaki malzemelere bakarak, bunların katı ve renkli bir madde olduğundan bahseder, birisinin sarı diğerinin turuncu renkte olduğunu söylerler. Bundan dolayı, 1. çözeltinin sarı, ikinci çözeltinin turuncu renkte olması gerektiğinden bahsederler. Bu aşamadan sonra diyalog şöyle gerçekleşir: 
Teoriden Uygulamaya Argümantaston Tabanlı Bilim Öğrenme (ATBÖ) Yaklaşımı: Kimya Laboratuvarlarında Uygulama Örneği
Ö: $\quad$ Siz burada bunlara bakarak neyi anlamayı planllyorsunuz?
Ö12: $\quad$ Renk değişimini.
Ö: $\quad$ Bu bă̆lamda, 3. deney tüpüne ne katacaksınız?
Ö13: $\quad \mathrm{HCl}$.
Ö: $\quad \mathrm{K}_{2} \mathrm{CrO}_{4}$ üzerine $\mathrm{HCl}$ ilave edeceksiniz, renk değişimini gözleyeceksiniz. Burada tepkimede ne görmeyi bekliyorsunuz? Yazalım bir denklemi.

$\ddot{\mathrm{O}} 13, \mathrm{~K}_{2} \mathrm{CrO}_{4}+\mathrm{HCl} \rightarrow$ denklemini yazar.

Ö: $\quad$ Eklendiğinde bir madde çıkacak değil mi?

Ögrenciler: Evet.

Ö: $\quad$ Mesela $\mathrm{A}$ maddesi çıktı diyelim. $\mathrm{K}_{2} \mathrm{CrO}_{4}+\mathrm{HCl} \rightarrow$ A. Sonrasında ne yapacaksınız? (Burada ögrretmen ögrencilere 1. ve 2. deney tüpündeki renklerle, son deney tüpündeki renklere bakması konusunda uyarır.) Sonra ne ilave edeceksiniz?

Öğrenciler: NaOH ilave edecĕ̌iz.

Ö: $\quad$ NaOH nereye ilave edeceksiniz?

Öğrenciler: A maddesinin üzerine NaOH ilave edeceğiz. B maddesi oluşacak.

$O ̈ 13$, tahtaya $A+N a O H \rightarrow B$ denklemini yazar.

Ö: $\quad$ Burada ne anlatmaya çalışacaksınız. Buradaki 3. deney tüpünde nasıl bir değişim meydana gelmiş? Tersinir, dengede olan bir tepkimeyi nasil ifade ediyorduk?

Ögrenciler: Çift ok ile ifade ediyorduk.

Ö: $\quad$ Siz burada ne yapacaksını?

Öğrenciler: Çift yönlü tepkimeyi, dengede olan tepkimeyi bulmamız lazım. Sonrasında tepkimeye madde ilave ettiğimizde mesela asit veya baz ilave ettiğimizde ne olacak ona bakmamız lazım.

Ö: $\quad$ Demek ki dengedeki tepkimeyi bulacak, sonrasında tepkimeye madde ilave ettiğinizde mesela burada asit ilave ettiğinizde ne olacak baz ilave ettiğinizde ne olacak. Ona göre karar vereceksiniz.

Öğretmen burada, yapılan işlemin tamam olup olmadığı konusunda tüm sınıfın onayını alır. Sonrasında diğer sorunun cevabına geçer. Öğrenciler hangi konsantrasyonla hangi hacimde asit ve baz alacaklarını kararlaştırır. Öğretmen sorulan soru gereği, sıcaklığın etkisini incelemek için ne yapmaları gerektiğini sorar. Cevaben bir öğrenci sıcaklık deneyiyle ilgili yapılmak istenilenleri tahtaya çizer. Öğrencilerden bir diğeri ise iki farklı düzenek çizer. Çizdiği düzenekler için sıcaklıklar değişken olarak gösterilir. $\mathrm{Bu}$ aşamada $\mathrm{Cu}\left(\mathrm{NO}_{3}\right)_{2}$ ve $\mathrm{NaCl}$ maddelerini ele alırlar. Bunların bir tanesinin sıcaklığını artırır. Diğerinin sıcaklığını azaltır. Burada öğretmen yapılan bu deneyin mantığının bir önceki deneyle aynı olup olmadığını, dengenin ne tarafa kaydığını nasıl anlayacaklarını sorar. Öğrenciler, deneyin mantığının aynı olduğunu söylerler. Burada, renk değişiminden yola çıkarak dengenin ne tarafa kaydığını anlayacaklarından, hazırlayacakları çözeltilerin derişimleri ve hacimlerinin ne kadar olması gerektiğinden bahsederler. Isıtma ve soğutma esnasında oluşacak tepkimelerin denklemlerini tahtaya " $\mathrm{Cu}\left(\mathrm{NO}_{3}\right)_{2}+\mathrm{NaCl} \rightarrow \mathrm{A}+1 \mathrm{~s} 1$ ve $\mathrm{A}+1 \mathrm{~s} 1 \rightarrow \mathrm{B}$ " şeklinde yazarlar. Laboratuvarda yapılan tartışma sonucunda derişimin ve sıcaklığın etkisiyle ilgili sınıf tahtasında oluşan çizimler Şekil 4 ve Şekil 5 'te gösterilmiştir. Şekil 4 ve 5, video ekran görüntüsü çekilerek oluşturulmuştur. 


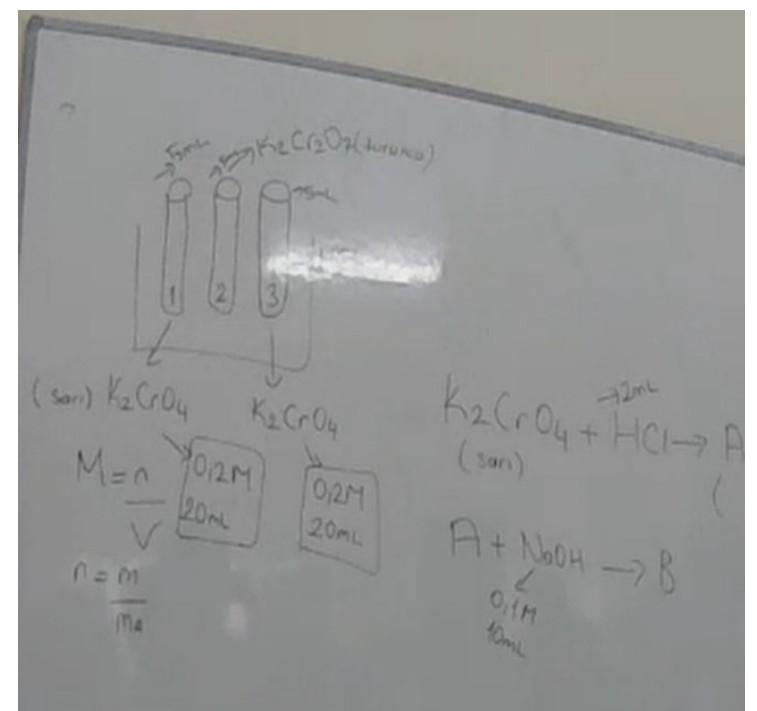

Şekil 4. Derişimin kimyasal dengeye etkisiyle ilgili video ekran görüntüsü

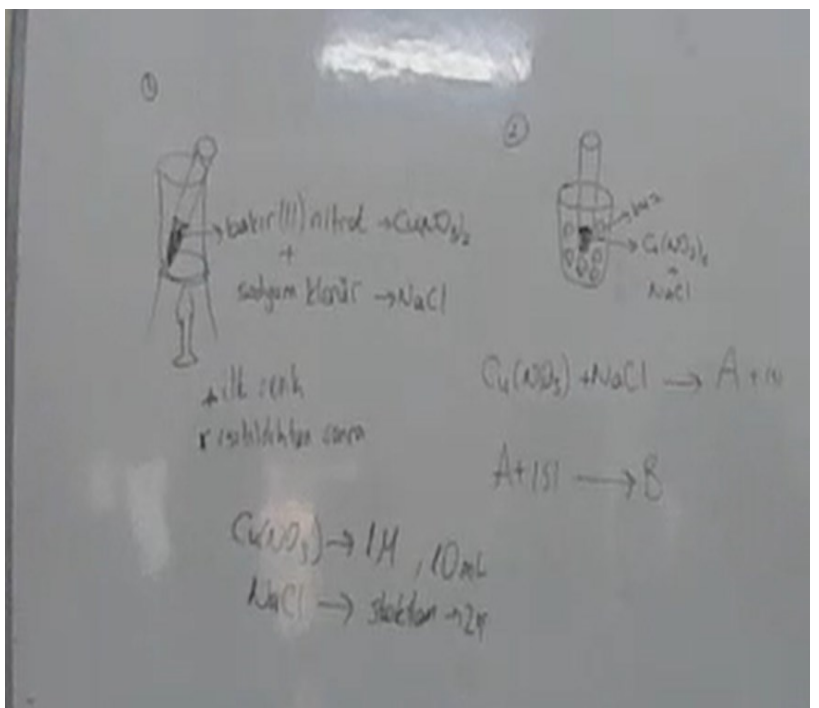

Şekil 5. Sicaklı̆̆ın kimyasal dengeye etkisiyle ilgili video ekran görüntüsü

Sonrasında ise sınıf başlangıç sorularına cevap verecek yöntem hakkında fikir birliğine vararak deneye başlarlar. Yukarıdaki her iki örnekte görüldüğü gibi öğrenciler, bu aşamada hem Ö-G-Ç ile akı1 yürüterek argümantasyon yapmakta, hem de gerçekleşen diyaloglar ve bu diyaloglar esnasında tahtaya çizilen çoklu-gösterimler ile dili bir öğrenme aracı olarak kullanmaktadırlar. Dikkat çeken diğer konu ise, öğrencilerin yaptıkları tartışma esnasında kimyadaki makroskobik, mikroskobik ve sembolik çoklugösterimleri kullanmaları için herhangi bir vurgu yapılmadığı halde, iddia ve kanıtlarını desteklemek için kullanmalarıdır. Bu durum, argümantasyon ile dil kullanımının doğal olarak birbirini destekleyen iki husus olduğunu göstermesi açısından önemlidir. Yöntemin öğrencilerin laboratuvar raporlarında nasıl yazıldığı Şekil 6'da incelenebilir. Burada öğrencinin yöntem kısmına yazdıkları sadece yapılacakları özetlemektir. Öğrenci yöntem kısmında yapmış oldukları tartışmalarda kullandıkları formülleri, denklemleri vs. deney yapılış aşamasında göstermektedir (bknz. Şekil8, 9, 10).

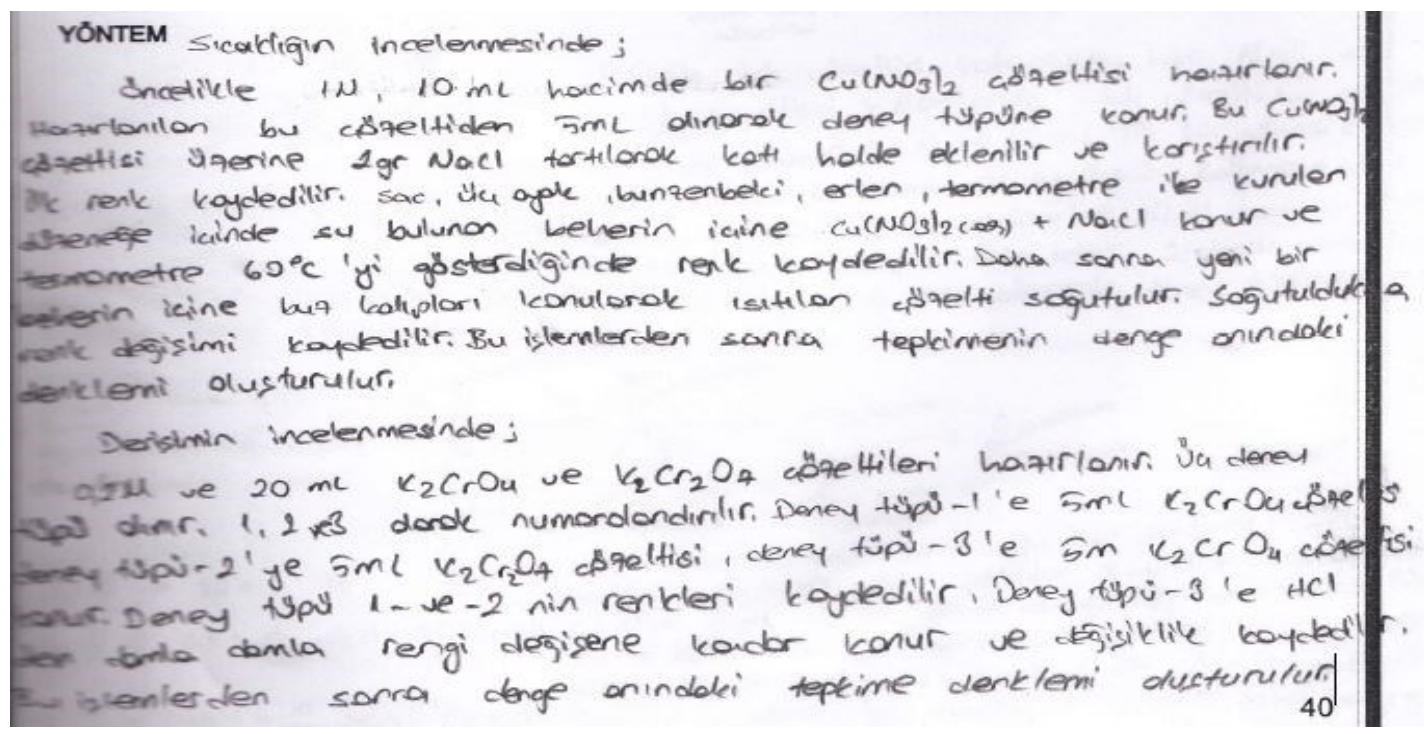

Şekil 6. Öğrencinin yöntem kısminda yazdlkları 


\subsubsection{Deneyin Yapılışı}

Deney aşamasında, öğrencilerden, gruplar arasında görev dağılımı yaparak kimin hangi verileri toplayacağını belirlemeleri ve işbirlikçi bir şekilde grup içi ve gruplar arası çalışmaları istenir. Öğretmen, gruplar arasında gezerek öğrencileri etkinlik üzerinde odaklanmaları için, grup ya da sınıfın tamamına yönlendirici sorular sorar. Her bir grup deneyden elde ettiği verileri tahtadaki tabloya girer. Grupların verileri birbirinden farklı olabilir. Önemli olan, öğrencilerin tablodaki örüntüleri görebilmeleridir. Öğrenciler grafik oluşturarak değişkenlerin birbirlerini nasıl etkilediklerini görebilir. Sonrasında, öğrenciler deneysel verilerini ve gözlemlerini Ö-G-Ç şeklinde akıl yürütme yaparak tartışırlar.

İncelenen örnek etkinliğe bakıldığında, öğrenciler kendi aralarında görev dağılımı yaparak, bir grup içindeki öğrencilerin bir kısmı derişimin etkisini incelemeyi seçerken, diğer bir kısmı ise sıcaklığın etkisini incelemeyi seçer. Bu esnada, öğretmen, öğrencilerin daha detaylı ve derinlemesine gözlem yapmaları için, deneyle ilgili yönlendirici sorular sorar, öğrencilerden gelen soruları ise, cevap olabilecek şekilde cümleler kurmak yerine diğer öğrencilere yönlendirir. Öğretmen, bu sayede grup içi diyalog ve tartışmaya kapı açar. Öğrenciler, deneyleri bitirdikten sonra deneydeki denklemleri yazmaya çalışır. Burada öğretmen de öğrencilerle beraber denklemleri onlara doğru cevapları göstermeden, öğrencilerle tartışır. Sonrasında, gruplar topladıkları verileri sınıf tablosuna girerler (Şekil 7). Sınıf tablosunda, derişimin dengeye etkisi ilk sütunda, sıcaklığın dengeye etkisi etkinliğiyle ilgili kısım ikinci sütunda belirtilmiştir.

\begin{tabular}{|c|c|c|c|}
\hline 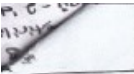 & $\begin{aligned} \mathrm{K}_{2} \mathrm{CrO}_{4}+\mathrm{HCl} & \longrightarrow A \\
A+\mathrm{NaOH} & \longrightarrow B\end{aligned}$ & $\mathrm{Cu}\left(\mathrm{NO}_{3}\right)_{2}+\mathrm{NaCl}$ Cistelenca - & socputulunca) \\
\hline 1. Grup & $\begin{array}{l}\mathrm{K}_{2} \mathrm{CrO}_{4}+\mathrm{HCl} \rightleftarrows \mathrm{KCl}+\mathrm{Cr}_{2} \mathrm{O}_{i}^{-}+\mathrm{H}^{+} \\
\mathrm{Cr}_{3} \mathrm{O}_{4}^{-}+\mathrm{NeOHH} \geq \mathrm{Cr}_{2}+\mathrm{OH}^{-}+\mathrm{NaO}_{4}^{-}\end{array}$ & $\begin{array}{l}\mathrm{Cu}\left(\mathrm{NO}_{3}\right)_{2}+\mathrm{NaCl} \rightarrow \mathrm{CuCl}_{2}+\mathrm{NOW}_{2} \mathrm{NO}_{3} \\
\mathrm{Cu}^{+2}+\mathrm{Cl}^{-} \longleftarrow \mathrm{CuCl}_{2}\end{array}$ & $\begin{array}{l}\text { ari tiekas } \\
\text { lerition do }\end{array}$ \\
\hline 2. frue & $\begin{array}{l}\mathrm{CrO}_{4}^{-2}+\mathrm{H}^{+} \longrightarrow \mathrm{Cr}_{2} \mathrm{O}_{4}^{-2}+\mathrm{H}_{2} \mathrm{O} \\
\mathrm{Cr}_{2} \mathrm{O}_{7}^{-2}+\mathrm{OH}^{-} \longrightarrow \mathrm{CrO} u^{-2}+\mathrm{H}_{2} \mathrm{O}\end{array}$ & $\begin{array}{l}\mathrm{Cu}^{+2}+\mathrm{Cl}^{-} \underset{\mathrm{s}}{\stackrel{i}{\rightleftarrows}} \mathrm{CuCl}_{2} \\
\left.\mathrm{Cu}\left(\mathrm{NO}_{3}\right)_{2}+\mathrm{NaCl} \rightarrow \mathrm{CuCl}_{2}+\mathrm{Na}(\mathrm{NO})_{3}\right)\end{array}$ & Meri sondo \\
\hline 3. Exup & $\begin{array}{l}\mathrm{CrO}_{4}^{-2}+\mathrm{H}^{+} \rightleftharpoons \mathrm{Cr}_{2} \mathrm{O}_{4}^{-2}+\mathrm{H}_{2} \mathrm{O} \\
\mathrm{Cr}_{2} \mathrm{O}_{7}^{-2}+\mathrm{OH}^{-} \rightleftharpoons \mathrm{CrO}_{4}^{-2}+\mathrm{H}_{2} \mathrm{O}\end{array}$ & $\begin{array}{l}\mathrm{Cu}^{+2}+\mathrm{Cl}^{-}+\frac{1}{4} \mathrm{CuCl}_{2} \\
\mathrm{Cu}(\mathrm{NO})_{2}+\mathrm{NaCl} \rightarrow \mathrm{CuCl}_{2}+\mathrm{Na}_{\left(\mathrm{NO}_{3}\right)}\end{array}$ & $\begin{array}{l}\text { iloritends } \\
\text { afris }\end{array}$ \\
\hline 4. Grup & $\mathrm{CrO} \mathrm{O}^{-2}+\mathrm{H}^{+} \rightleftarrows \mathrm{Cr}_{2} \mathrm{O}_{7}^{-2}+\mathrm{H}_{2} \mathrm{O}$ & 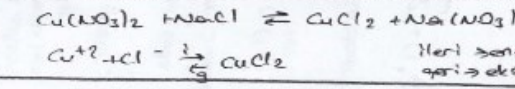 & $\begin{array}{l}\text { I/2 } \\
\text { ando } \\
\text { exas }\end{array}$ \\
\hline 5. brue & $\mathrm{CrO}_{4}^{-2}+\mathrm{H}^{+} \rightleftharpoons \mathrm{Cr}_{2} \mathrm{O}_{7}^{-2}+\mathrm{H}_{2} \mathrm{O}$ & 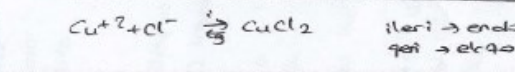 & \\
\hline 6. Grup & $\begin{array}{l}\mathrm{CrO}_{4}^{-2}+\mathrm{H}^{+} \rightleftharpoons \mathrm{Cr}_{2} \mathrm{O}_{7}^{-2}+\mathrm{H}_{2} \mathrm{O} \\
\mathrm{Cr}_{7} \mathrm{O}_{7}^{-2}+\mathrm{OH}^{-} \rightleftharpoons \mathrm{CrO}_{4}^{-2}+\mathrm{H}_{2} \mathrm{O}\end{array}$ & $\mathrm{NaCl}+\mathrm{CuCNO} \mathrm{O}_{2} \rightleftharpoons \mathrm{NaNO}$ + CuC & $\begin{array}{l}\mathrm{Cl}^{\prime} 2 \\
\text { Keri } \rightarrow \text { endo } \\
\text { gerimekpo }\end{array}$ \\
\hline
\end{tabular}

Şekil 7. Sinıf tablosu

Laboratuvar raporlarına bakıldığında, öğrenciler deneyin yapılışını ve topladıkları verileri sayısal, sözel, denklem, formül ve şekillerle sunarlar. Öğrencilerden veri ve gözlemleri düzgün bir şekilde organize etmeleri, hesaplamalardaki bütün basamakları uygun bir şekilde göstermeleri, önemli şekil ve birimleri doğru bir şekilde kullanmaları beklenmektedir. Ayrıca, bu kısımda öğrencilerin verileri nasıl ve niçin topladığını gösterir bir anlamayı sergilemeleri beklenir. Örnek olarak, Şekil 8'de öğrenci deney esnasında kullandığı araç-gereçlerin (mezur, balon joje, deney tüpü) ve kimyasal malzemelerin $\left(\mathrm{K}_{2} \mathrm{CrO}_{4}, \mathrm{~K}_{2} \mathrm{Cr}_{2} \mathrm{O}_{7}\right.$, saf su) isimlerini yazarak şekillerini çizmiştir. Ayrıca, çözelti hazırlamak için gerekli formülleri ve cebirsel işlemleri yapmış ve hesapladığ bu değerle bir çözeltinin nasıl hazırlandığını, yaptığı işlemlerin yan tarafına açıklamıştır. Bu bağlamda, öğrenci, $0,2 \mathrm{M} 20 \mathrm{~mL}$ $\mathrm{K}_{2} \mathrm{CrO}_{4}$ çözeltisi hazırlamak için stok çözeltisinden alması gereken 0,77 gr $\mathrm{K}_{2} \mathrm{CrO}_{4}{ }^{\prime} \mathrm{t}$ I $\mathrm{M}=\mathrm{n} / \mathrm{V}$ ve $\mathrm{n}=\mathrm{m} / \mathrm{MA}$ formüllerini kullanarak nasıl hesapladığını, $20 \mathrm{~mL}$ saf suyu mezürü kullarak nasıl ölçtüğünü, çözeltiyi balon jojede nasıl hazırladığını ve 1 ve 3 nolu deney tüplerine hazırladığı sarı renkli $\mathrm{K}_{2} \mathrm{CrO}_{4}$ çözeltisiden $5 \mathrm{~mL}$ ilave ettiğini göstermiştir. 


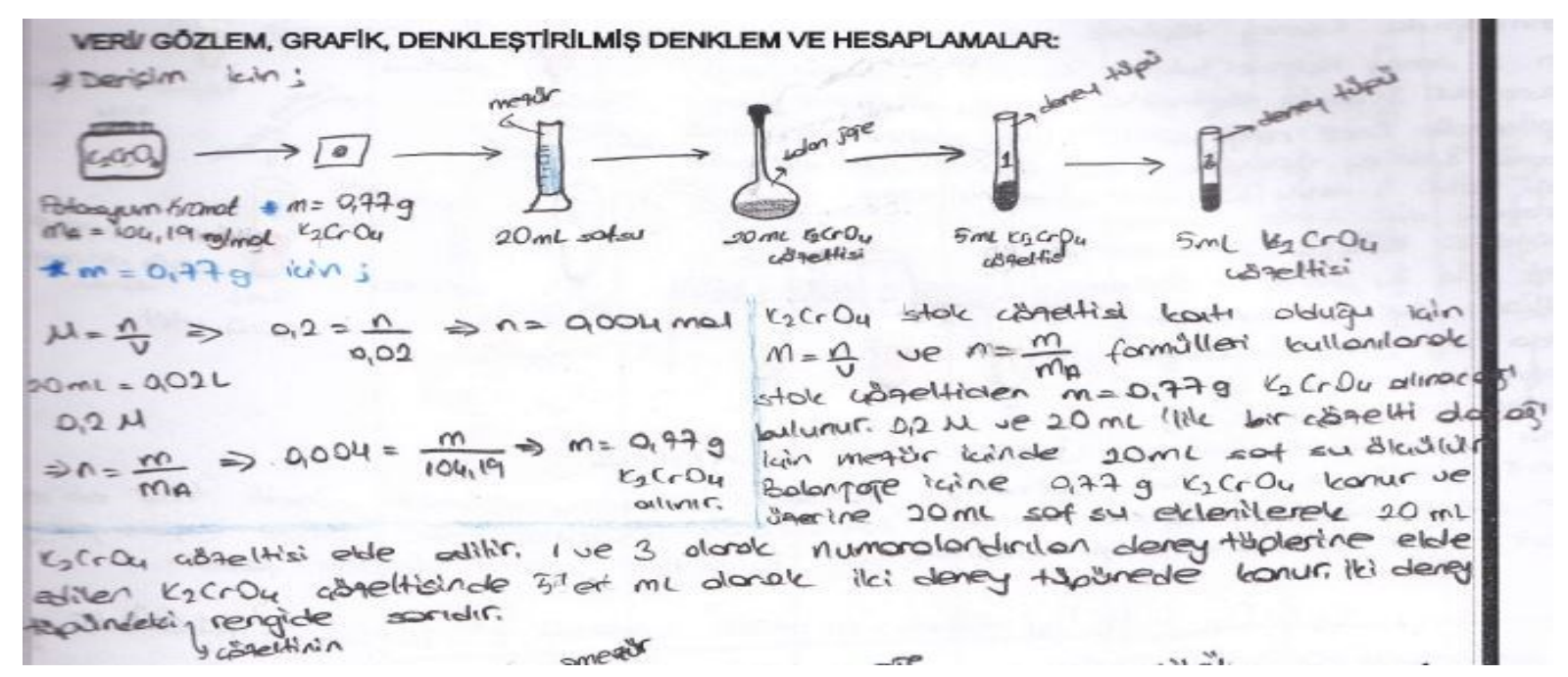

Şekil 8. Öğrencinin gözlem kısmına yazdı̆̆ kayıtlardan bir kısım

Sonrasında ise, kimyasal dengeye derişimin ve sıcaklığın etkisi ile ilgili elde ettiği verileri gözlem kısmına yazmıştır (Şekil 9 ve 10). Öğrenci, her iki etkinlikte kullandığı deney araç gereçlerini (deney tüpü, saç ayak, termometre, bunzen beki, beher vs) ve kimyasal malzemeleri $\left(\mathrm{K}_{2} \mathrm{Cr}_{2} \mathrm{O}_{4} ; \mathrm{K}_{2} \mathrm{Cr}_{2} \mathrm{O}_{7} ; \mathrm{HCl}\right.$; $\left.\mathrm{NaOH} ; \mathrm{Cu}\left(\mathrm{NO}_{3}\right)_{2} ; \mathrm{NaCl}\right)$ yazmış ve yaptı̆ğ işlemler sonucunda meydana gelen değişimleri şekil, denklem vs şeklinde ifade etmiştir. Uygun birimleri ve şekilleri göstermiş, bunlarla ilgili gerekli açıklamaları yapmıştır. Ayrıca, çözeltilerin renklerini gerçek renklerle eşleştirmiştir. Yaptı̆̆ deneyi ve burada elde ettiği verileri nasıl ve niçin elde ettiğini gösterir bilgiyi, çizdiği şekil ve denklemlerin altına ya da yanına yazmıştır. Bu bağlamda, Şekil 9'da, öğrenci 1. ve 3. deney tüplerine $5 \mathrm{~mL} \mathrm{~K}_{2} \mathrm{CrO}_{4}, 2$. deney tüpüne $5 \mathrm{~mL} \mathrm{~K}_{2} \mathrm{Cr}_{2} \mathrm{O}_{7}$ ilave ettiğini deney tüplerini ve çözeltilerin almış olduğu renkleri gözlemlediği renklerde çizerek göstermiştir. $\mathrm{Bu}$ bağlamda, $5 \mathrm{~mL} \mathrm{~K} \mathrm{CrO}_{4}$ çözeltisini sarı, $\mathrm{K}_{2} \mathrm{Cr}_{2} \mathrm{O}_{7}$ çözeltisini turuncu renkli çizmiştir. Ayrıca, 3. deney tüpünü yaptığı iki işlem basamağını da hemen yan tarafına çizmiş ve çözeltilerin bu durumda aldığı renkleri ve maddeleri altına yazmıştır. Diğer bir ifadeyle, öğrenci 3. deney tüpüne birinci işlem olarak $2 \mathrm{~mL} \mathrm{HCl} \mathrm{çözeltisi} \mathrm{damlatmış} \mathrm{çözeltinin} \mathrm{renginin}$ turuncuya döndüğünü ve bu aşamada meydana gelen olayın denklemini a) kısmında $\mathrm{CrO}_{4}^{-2}+\mathrm{H}^{+} \rightarrow$ $\mathrm{Cr}_{2} \mathrm{O}_{7}{ }^{-2}$ olarak ifade etmiştir. 3. deney tüpüne yapmış olduğu ikinci işlem basamağında $\mathrm{NaOH}$ çözeltisi ilave edildiğini ve bu işlem sonucunda turuncu renkli çözeltisinin renginin tekrar sarıya döndügünü ve bu aşamada meydana gelen olayın denklemini b) $\mathrm{Cr}_{2} \mathrm{O}_{7}^{-2}+\mathrm{OH}^{-} \rightarrow \mathrm{CrO}_{4}^{-2}$ şeklinde ifade etmiştir. Sonrasında da denge halini $\mathrm{CrO}_{4}{ }^{-2}+\mathrm{H}^{+} \leftrightarrow \mathrm{Cr}_{2} \mathrm{O}_{7}{ }^{-2}+\mathrm{H}_{2} \mathrm{O}$ şeklinde ifade edip bu denklemde oluşan $\mathrm{H}_{2} \mathrm{O}^{\prime}$ un a) tepkimesindeki $\mathrm{H}^{+}$ve b) tepkimesindeki $\mathrm{OH}^{-}$iyonları sonucunda oluştuğunu ifade etmiştir. 


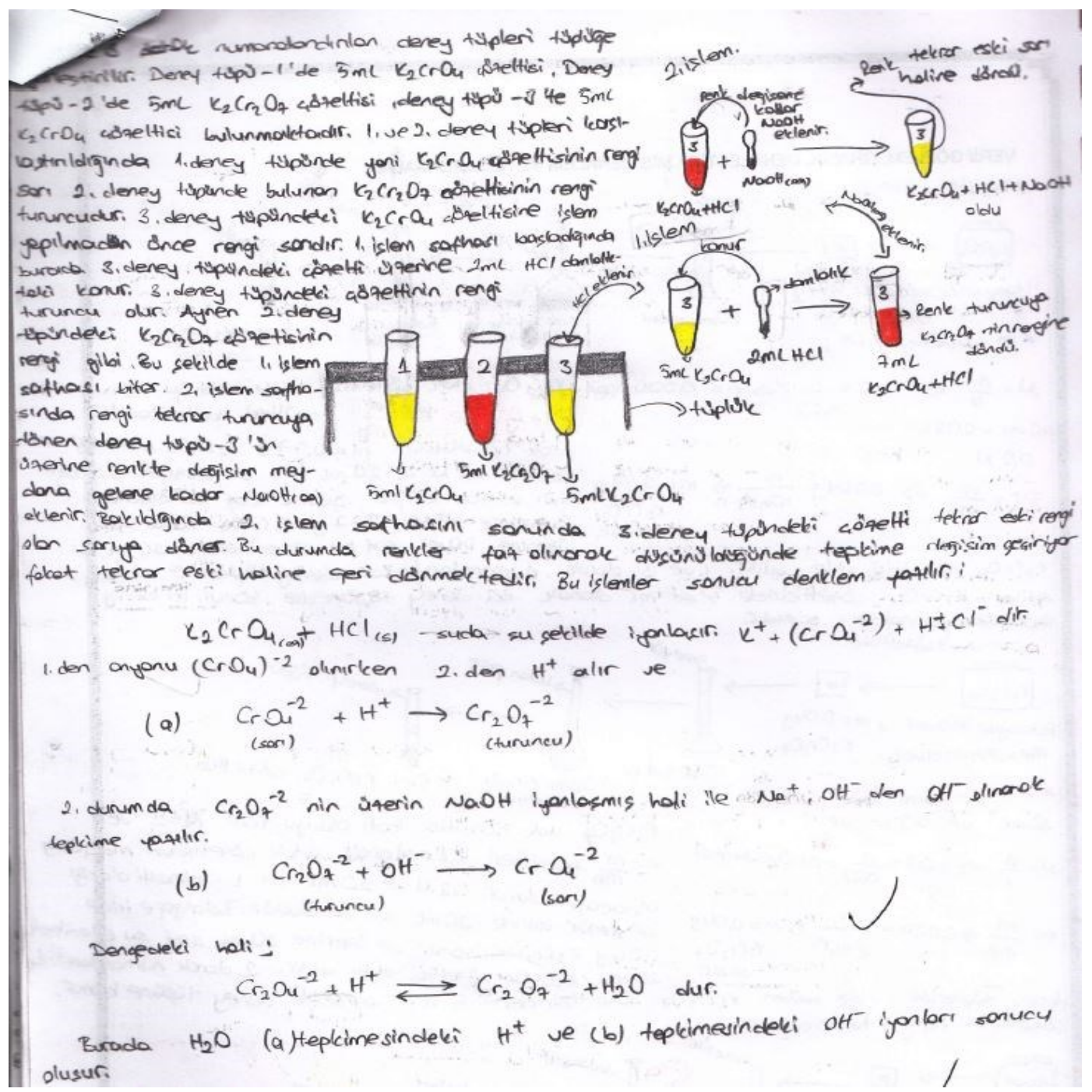

Şekil 9. Öğrencinin derişsim ile ilgili yazdlğı deney gözlemi

Öğrenci, sıcaklığın dengeye etkisini incelediği (Şekil10) etkinlikte üç işlem yapmıştır. Birinci işlemde, $\mathrm{Cu}\left(\mathrm{NO}_{3}\right)_{2}$ çözeltisinin üzerine $\mathrm{NaCl}$ ilave etmiş renginin yeşile döndügünü kaydetmiştir. İkinci işlemde, birinci işlemdeki yeşil renkli çözeltiyi hazırladıkları düzeğin içerisine yerleştirmiş ve $60^{\circ} \mathrm{C}$ ye kadar ısıtmıştır. Öğrenci, bu ısıtma işlemini ileri yöndeki tepkime ve endotermik olarak ifade etmiştir. $\mathrm{Bu}$ olayın denklemini alt kısımda a) $\mathrm{Cu}^{+2}+\mathrm{Cl}^{-}+1 \mathrm{~S} 1 \rightarrow \mathrm{CuCl}_{2}$ olarak ifade etmiş ve çözeltinin renginin maviden yeşile döndügünü yazmıştır. 3. işlemde, 2. işlemdeki deney tüpünü buz dolu bir beherin içerisine yerleştirmiş ve çözeltinin renginin tekrar yeşile döndüğünü ve bu olayın denklemini b) $\mathrm{CuCl}_{2}$ $\rightarrow \mathrm{Cu}^{+2}+\mathrm{Cl}^{-}+1$ sı olarak ifade etmiştir. Bu gerçekleşen olayın geri yöndeki bir tepkime olduğunu ve ekzotermik olduğunu yazmıştır. Öğrenci denge halindeki tepkimeyi $\mathrm{Cu}^{+2}+\mathrm{Cl}^{-} \leftrightarrow \mathrm{CuCl}_{2}$ olarak ifade etmiştir. 


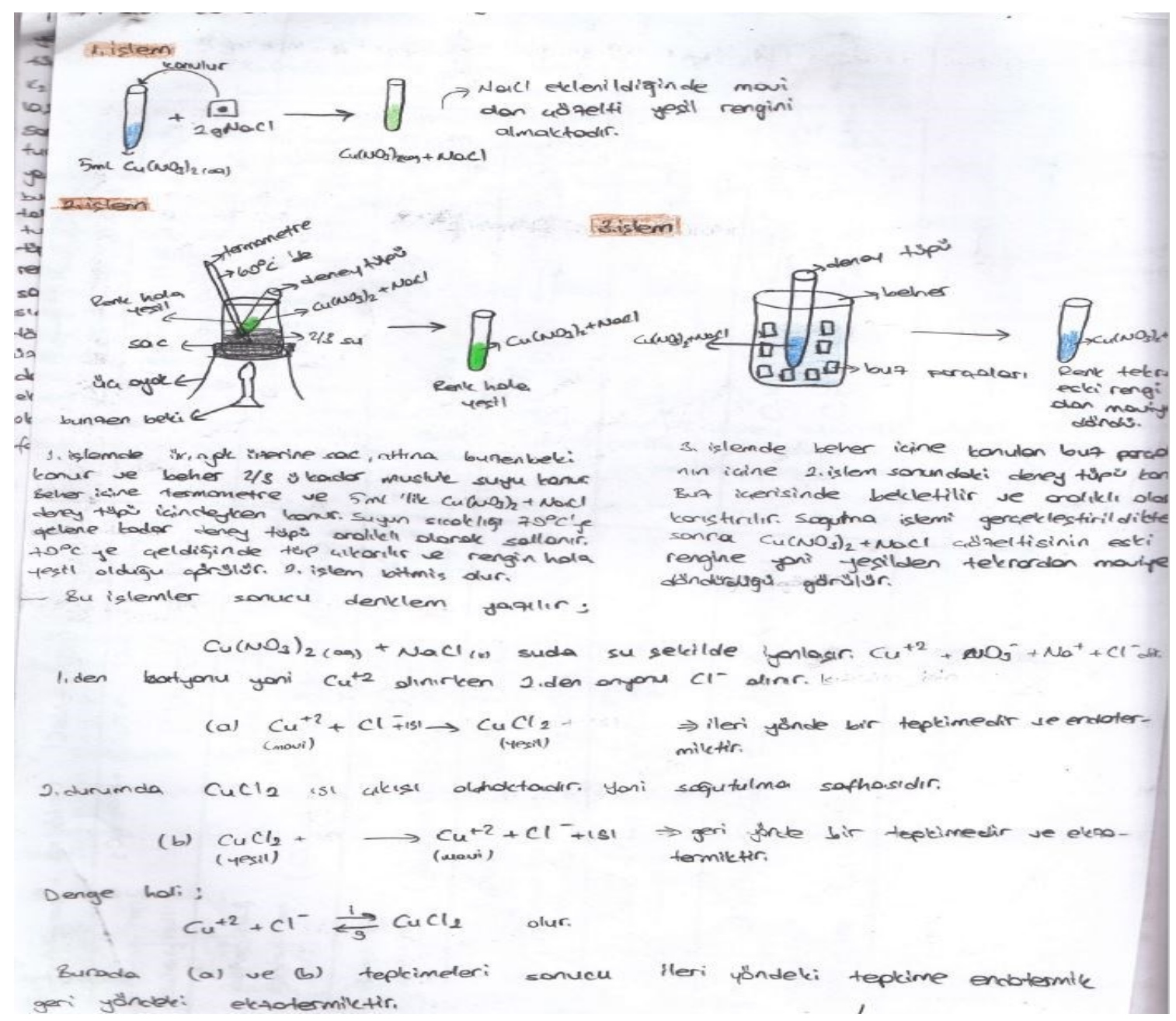

Şekil 10. Öğrencinin sıcaklı̆̆ın dengeye etkisi etkinliği ile ilgili yazdlklarl

\subsection{4. İddia ve Kanıt Oluşturulması}

Öğrencilerin, deneylerinden topladıkları verilerle iddia ve kanıtlarını oluşturmaları beklenir. Bunu yaparken, başlangıç soruları, gözlem, veri, iddia ve kanıtları arasında açık bağlantı kurmaları gerekir. İddia, laboratuvar çalışmasının sonucuyla alakalı bir ya da iki cümle olabilir. Öğrencilerden, yaptıkları araştırma ile ilgili bir iddiada bulunurken, bir örüntü yakalamaları, bir genelleme yapmaları, bir ilişkiyi açığa çıkarmaları ya da yaptıkları çalışmayla açığa çıkarılacak bir açıklama yapmaları beklenir. Örneğin, "Dengede olan bir sistemde ürünler tarafında dışarıdan madde ilave edildiğinde denge girenler tarafına kayar." şeklinde bir ifade uygun bir iddia olurken, "Ürünümün rengi turuncu olur." şeklindeki bir ifade uygun olmayan bir iddiadır. Öğrencilerden, kanıt oluştururken iddialarını destekleyen sözlü/yazılı açıklamalar yapmaları beklenir. Toplanan verilerin yorumlanması ile, yani, veri üzerinden tatmin edici gerekçelendirmeler yapılarak kanıt oluşturulması gerekir. Öğrencilerin, kanıt için sadece gözlemlerin anlatılmamasının farkında olması gerekir. Bu farkındalık için, özellikle ATBÖ’ye başlandığı ilk derslerde, kanıtın nasıl olması gerektiği konusunda öğretmen rehberliği çok önemlidir. Ayrıca, öğrencilerin iddia ve kanıtlarını oluştururken denklem, şekil, grafik gibi çoklugösterimleri kullanması, öğrencilerin öğrenmeleri için dil unsurlarını bir araç olarak kullandığını göstermektedir.

İncelenen örnekte öğrencinin bulunduğu grup iki iddiada bulunmuştur: "1. Bir kimyasal tepkimede ileri yöndeki tepkime endotermik ise geri yöndeki tepkime ekzotermiktir. 2. Denge halindeki bir tepkimede, denge, girenlere madde eklediğimizde ürünlere, ürünlere madde eklediğimizde girenlere kayar" şeklindedir. Öğrencilerden kanıt kısmında, "Nasıl bilebilirim? Bu iddiaları niçin yapıyorum?" sorularına cevap olacak şekilde iddialarını destekleyen açıklamalar yapmaları beklenmektedir. Veri ve hesaplamaların ardındaki anlamı açıklamaları istenmektedir. Burada grafiklerin, denkleştirilmiş denklemlerin ve hesaplamaların kanıt olarak sayılabilmeleri için yorumlanmaları ve açıklanmaları 
gerekmektedir. İddiaları desteklemek için uygun matematiksel hesaplamalar ve denkleştirilmiş denklemler kullanılabilir. Burada önemli olan bu sonuçların açıklanması ve yorumlanmasıdır.

Öğrenciler, grupça yaptıkları iddia ve kanıtlardan sonra sınıf tartışmasına başlar. Daha önceden de ifade edildiği gibi her grubun verisi tahtada yazılıdır. Bu yüzden, sınıf tartışmasında, sınıf tablosundaki veriler de tartışılabilmektedir. Sınıf tartışmasında her gruptan bir sözcü seçmeleri istenir. $\mathrm{Bu}$ esnada bir grup kendi iddialarını söylemekte diğer gruplarda bu grubun iddia ve kanıtlarını destekleyecek ya da çürütecek şekilde iddialarını kritik etmektedir. Burada öğrenciler, kanıtlarında sadece gözlemlerini değil denklem vs gösterek kanıtlamaya çalışırlar. Öğretmen yapılan tartışmaların sonucunda herkesin aynı fikirde olup olmadığını sorarak tartışmayı yönetir. Sınıf tartışmasında, bir grup iddiasını desteklemek için kanıtını şöyle gerekçelendirir:

Renk değişimi en büyük kanıt. Başlangıçta sarı renkli potasyum kromat $\left(\mathrm{K}_{2} \mathrm{CrO}_{4}\right)$ vardı. Hidroklorik asit ilave ettik, sonra turuncu renkli potasyum dikromat $\left(\mathrm{K}_{2} \mathrm{Cr}_{2} \mathrm{O}_{7}\right)$ elde ettik (Burada ögrenci, tahtaya yazılı olan kimyasal denklemi gösterir). Denklemlerden de görüldüğ̈̈ gibi, sonra ürünlere sodyum hidroksit ilave ettik, tekrar sarı renkli potasyum kromat $\left(\mathrm{K}_{2} \mathrm{CrO}_{4}\right)$ elde ettik. Tepkimenin denge olduğunu anladık. Burada, denge halinde bir sisteme, ürünler tarafina madde eklediğimizde dengenin girenler tarafina kaydığına, girenler tarafinda madde eklediğimizde dengenin ürünler tarafına kaydı ğını anladık.

Bir başka grup temsilcisi ise yapılan sıcaklık deneyindeki denklemleri ve deney şeklini gösterek çoklu-gösterimler ile gerekçelendirmesini yapar:

Illk başta elimizde $\mathrm{Cu}\left(\mathrm{NO}_{3}\right)_{2}$ ve $\mathrm{NaCl}$ 'ün tepkimesinden dolayı mavi renk vardl. Sonrasında ısıttı̆̆ımızda elde ettiğimiz ürün $\mathrm{CuCl}_{2}$ yeşil renk oldu. Oluşan ürünü, soğuttuğumuzda, tekrar mavi rengi elde ettik. Bu da bize tepkimenin dengede olduğunu, denklemlerde de görüldüğ̈̈ gibi (tahtadaki denklemleri gösterir), ileri yöndeki bir tepkime endotermik ise, geri yöndeki tepkimenin ekzotermik olduğunu gösterir.

$\mathrm{Bu}$ aşamada, bazı grupların denklemleri doğru yazmadıkları görülür ve yapılan tartışma sonucunda gruplar hangi denklemlerin iddialarını kanıtladıkları üzerinde anlaşmaya varırlar. Aşağıda tartışmaların yapıldığı gruptaki bir öğrencinin iddia ve kanıt kısmındaki yazılı örneği yer almaktadır.

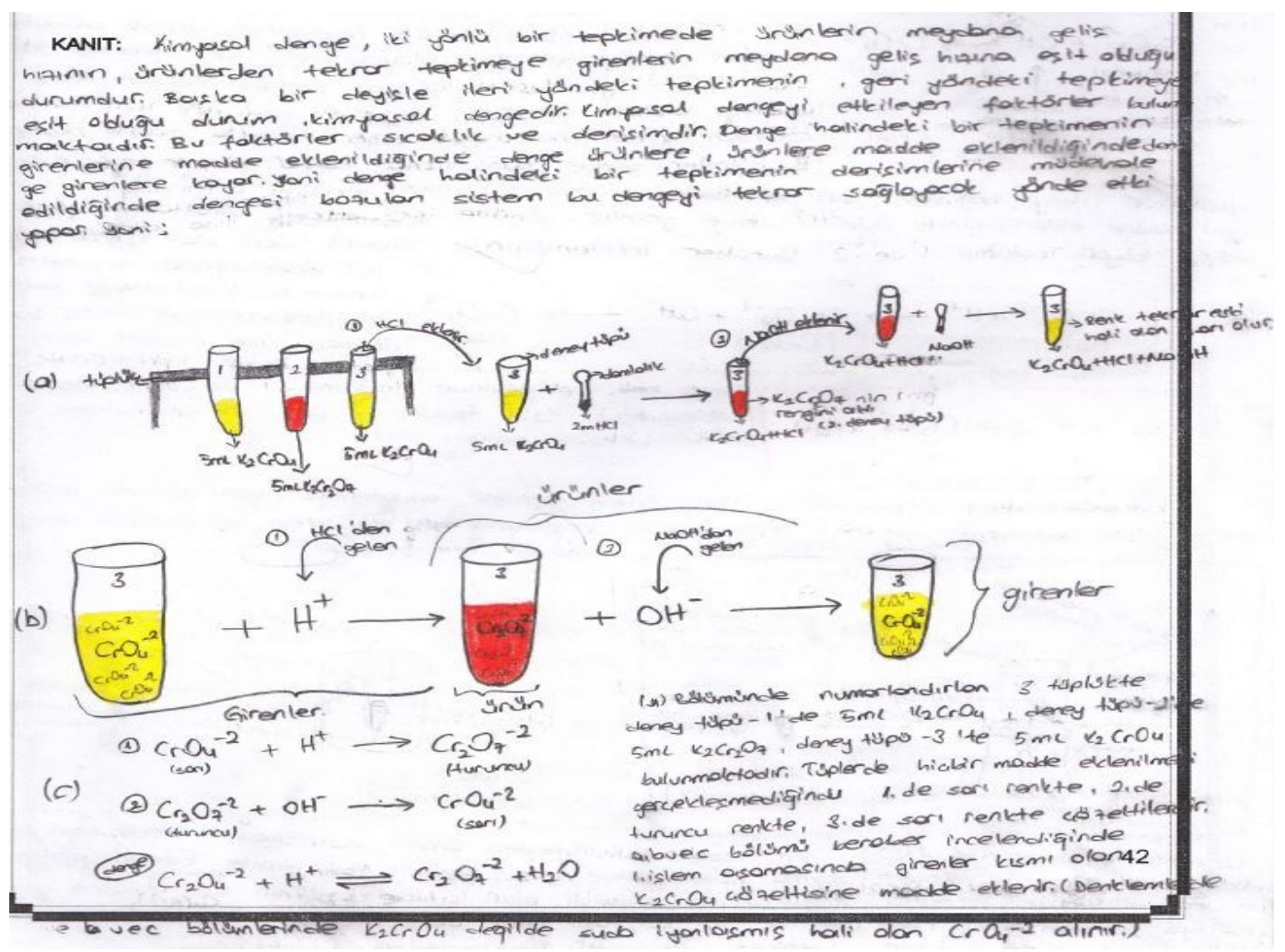

Şekil 11. Konsantrasyon etkinliğiyle ilgili kanıt kısmı 


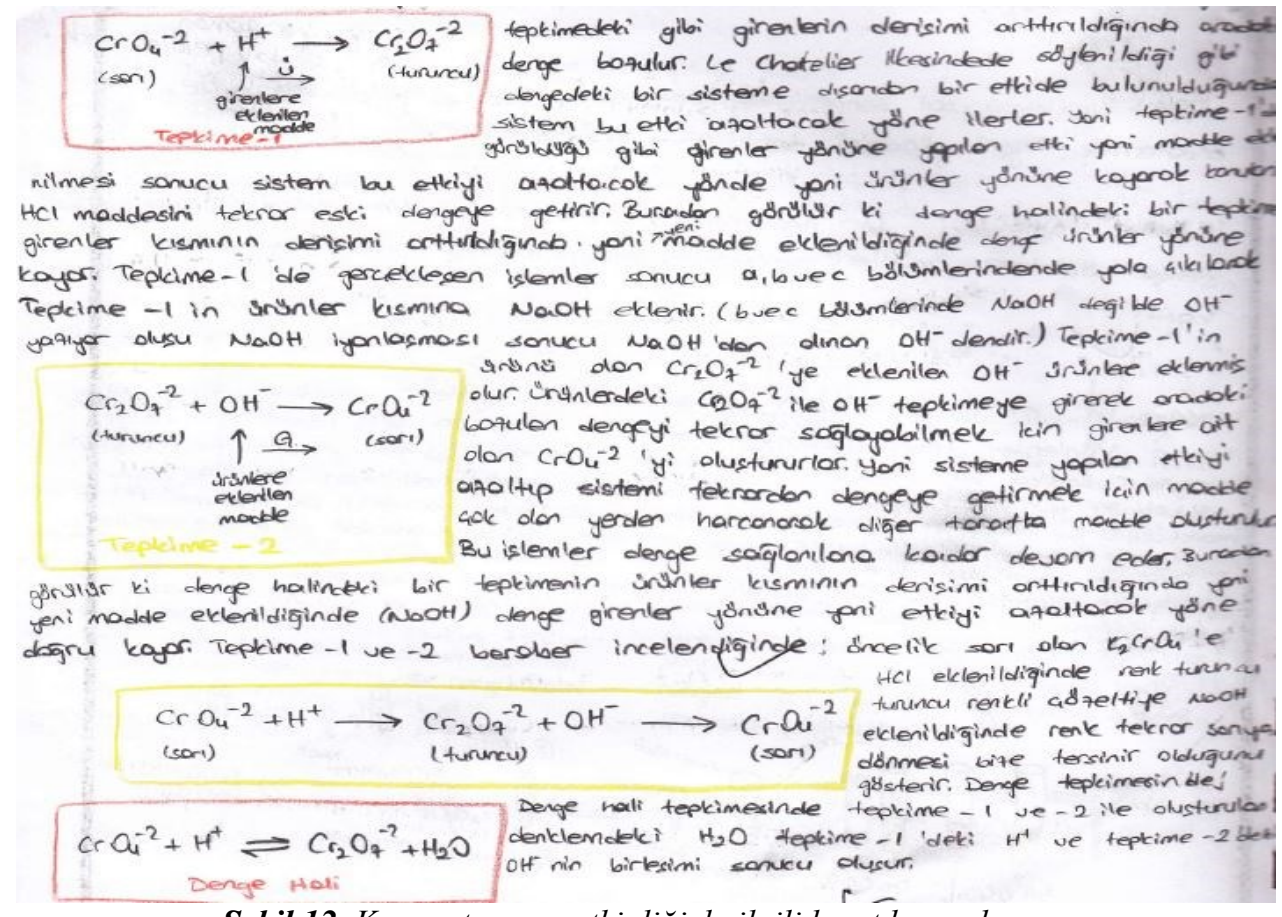

Şekil 12. Konsantrasyon etkinliğiyle ilgili kanıt kısmı devamı

Şekil 11 ve 12 aynı öğrencinin derişimin dengeye etkisiyle ilgili kanıt kısmını göstermektedir. Öğrenci, daha önceden de ifade edildiği gibi iki adet iddiada bulunmuştur. Bunlar derişimin ve sıcaklığın dengeye etkisiyle ilgilidir. Öğrenci, iddialarını kanıtlarken, Le Chatelier prensibinden yararlanmıştır ve yaptığ 1 etkinlerde elde ettiği verileri gerekçeleriyle birlikte açıklamıştır. Bu bağlamda öğrenci ilk olarak kimyasal dengenin “... ileri yöndeki tepkimenin geri yöndeki tepkime hızına eşit olduğu..." durum olduğundan bahsetmiştir. Bu etkileyen faktörlerden derişim ve sicaklık olduğunu ifade etmiş ve ilk olarak derişimin dengeye olan etkisini “... denge halindeki bir sistemin girenlerine müdahele edildiğinde..." sonrasında bu iddasını kanıtlamak için alt kısma deneyle ilgili şekil, denklem vs çizmiştir. Sonrasında bu çizdiklerini isimlendirmiş ve metin içerisinde kullanmıştır. Metin içerinde bu durumu Le Chatelier ilkesine göre kanıtlamaya çalışmıştır. Le Chatelier ilkesini “... dengedeki sisteme dişarıdan bir etkide bulunduğunda sistem bu etkiyi azaltacak yönde ilerler." şeklinde açiklar. Sonrasında bu durumu yaptıkları etkinlikle ilişkilendirir ve tepkime 1'i örnek gösterir (Şekil 12). Tepkime 1'de girenler kısmına $\mathrm{HCl}$ eklendiğinde sistemin ürünler tarafına nasıl kaydığını denklem üzerinde gösterir ve açıklar. Aynı şekilde tepkime 2'de dengedeki bir sisteme ürünler tarafındaki $\mathrm{NaOH}$ eklendiğinde sistemin girenler kısmına nasıl kaydığını renklerinin değişiminden yola çıkarak açıklar. Ayrıca, öğrenci yazdığı her iki denklemde kullandığı $\mathrm{H}^{+}$ve $\mathrm{OH}^{-}$iyonlarının gerekçelerinden bahseder.

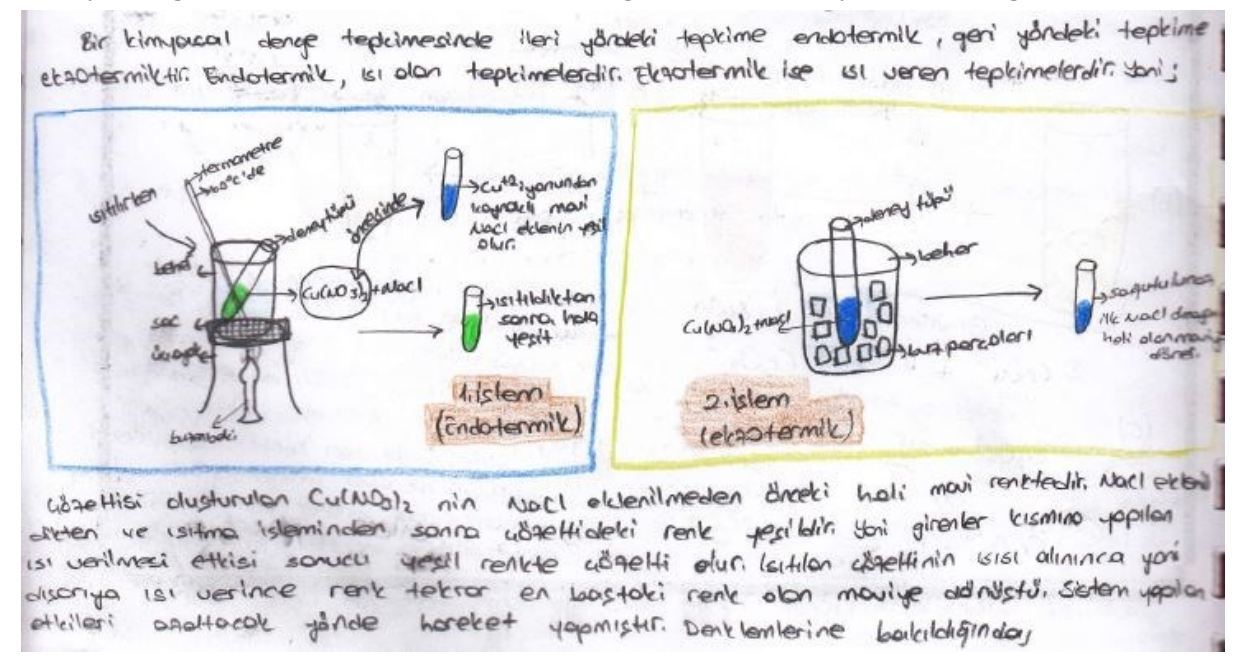

Şekil 13. Slcaklı̆̆ın kimyasal dengeye etkisi 


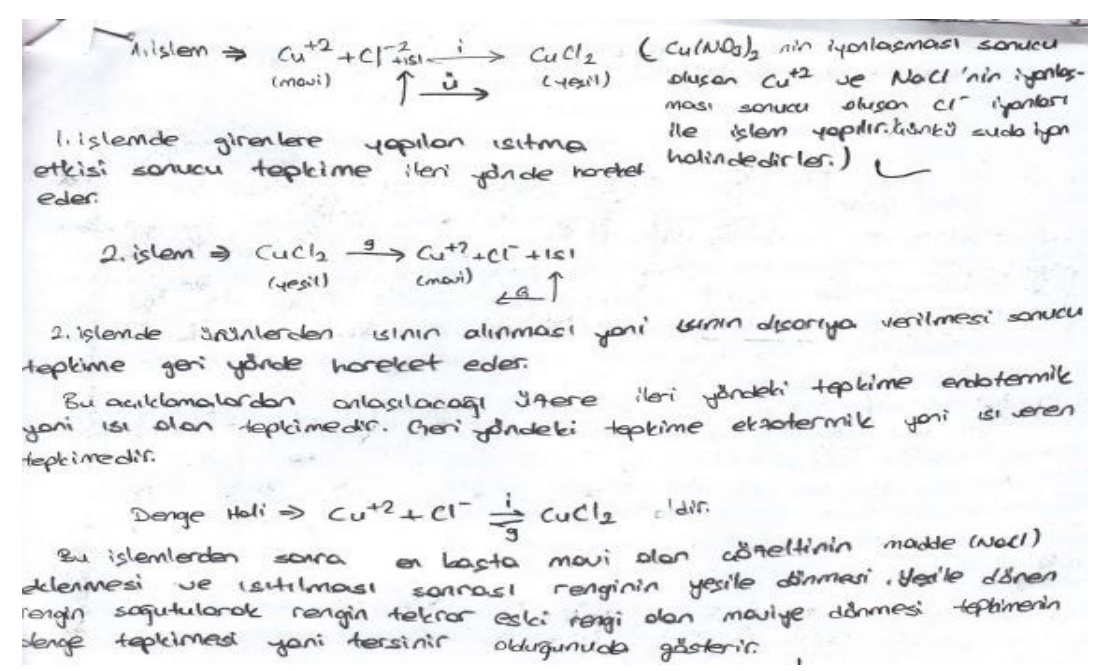

Şekil 14. Sicakllğın kimyasal dengeye etkisi devamı

Şekil 13 ve 14 ’te öğrencinin yazılı örnekleri incelendiğinde, öğrencinin denklemleri ve şekilleri yorumladığı, gerekçeler kullanarak kanıtladığı görülmektedir. Burada, öğrencilerden iddialarını tekrar ifade etmeleri ve mantıklı cümleler kurarak iddialarını savunmaları beklenmektedir. Öğrenciler yapılan sınıf tartışmasının ardından laboratuvardan ayrılırlar. Sonrasında, laboratuvar sonrasında yapılması gereken görevleri tamamlayarak raporlarını yazmaları beklenmektedir.

\section{3. АTBÖ Laboratuvar Sonrası (Okuma ve Yansıtma) Nasıl Olmaktadır?}

Öğrenci yansıtma kısmında başlangıçta ne düşündüğünü ve deney sonucunda düşünceleri arasında nasıl bir değişme olduğunu açıklar. Bu kısım öğrencilerin bilişsel ve üstbilişsel becerilerinin geliştiği yerdir. Bu aşamada öğrenciden birden fazla kaynaktan araştırma yapmaları, buradaki bilgileri iddia ve kanıtlarıyla direkt olarak ilişkilendirmeleri istenmektedir. Bu kaynakta yer alan bilimsel bilgileri kendi yaptıkları deney sonuçlarıyla ilişkilendirir. Burada mantıklı cümlelerle yaptıkları iddiaları kanıtlamaları ya da çürütmeleri beklenmektedir. Öğrenciler mantıklı cümlelerle kanıtlarının tamamını ya da büyük bir kısmını tanımlayıp açıklarken başlangıç sorularını ve değişen fikirlerini ifade etmektedir. Öğrenciler, böylelikle nihai sonuca varırlar.

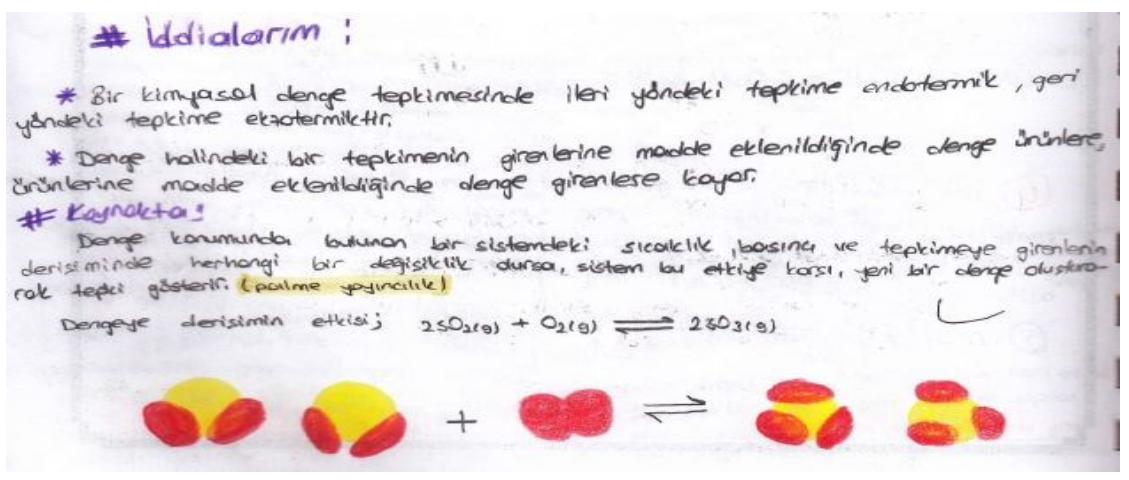

Şekil 15. Okuma ve yansıtma kısmı (Derişim) 


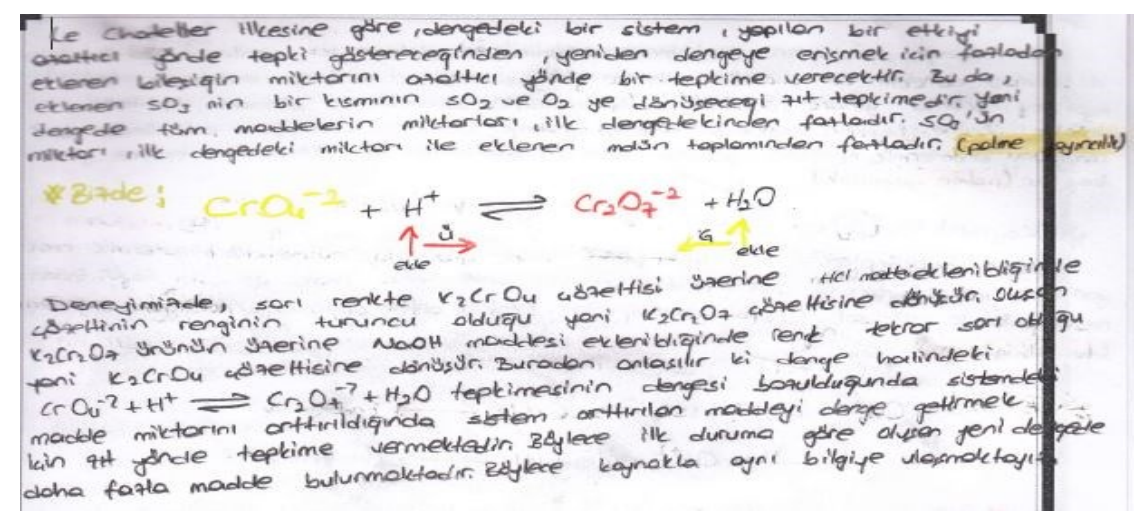

Şekil 16. Okuma ve yansıtma kısmı (Derişim) devamı

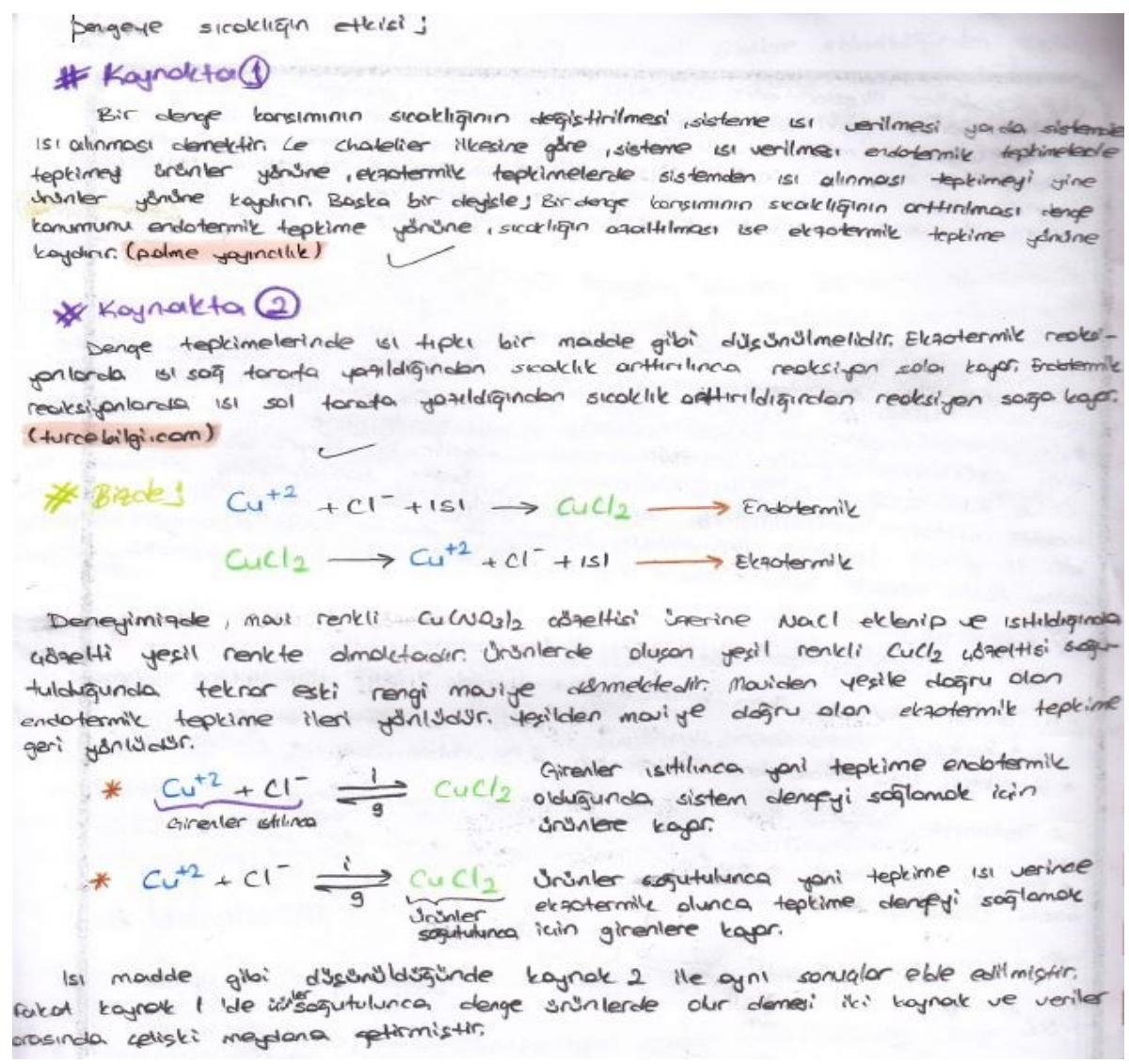

Şekil 17. Okuma ve yansitma kismı (Sicaklik)

Örnek bir yansıtma kısmı incelendiğinde, öğrenci öncelikle iddialarını belirtmiş, sonrasında ise incelediği kaynaktaki bilgilerin neler olduğundan bahsederek bu bilgilerin kendi iddiasını destekleyip desteklemediğini belirtmiştir. Bu bağlamda, Şekil 15'te de görüldüğg̈ gibi, öğrenci derişimin etkisi için Genel Kimya-II ders kitabında (Palme yayıncılıkta) yer alan bilgiyi kullanmıştır. Burada kitapta yer alan $\mathrm{SO}_{2}$ ve $\mathrm{O}_{2}$ arasında gerçekleşen tepkimeye örnek göstermiş ve Le Chatelier ilkesine göre yapılan açıklamayı yazmıştır (Şekil 16). Sonrasında ise, kendi yaptığı etkinlikteki denge tepkimesini yazmış ve olayı üst kısımda yazdığı bilgiye göre açıklamıştır. En sonunda da kaynaktaki bilgi ile sınıfta yapılan etkinlikte elde ettiği bilginin birbirine benzer olduğu sonucuna varmıştır (Şekil 16). Öğrenci sıcaklığın dengeye etkisi ile ilgili iki kaynak araştırması yapmıştır. Şekil 17'de de görüldüğü gibi, yaptığı kaynak araştırmasından sonra, kendi etkinliklerinde elde ettikleri sonuç ile kaynakların birinden elde ettiği sonucun çelişkili olduğunu ifade etmiştir. Şekil 18 'de görüldügüü gibi, öğrenci deney başlangıcında ve sonunda aynı fikirde olduğunu belirtmiştir. 


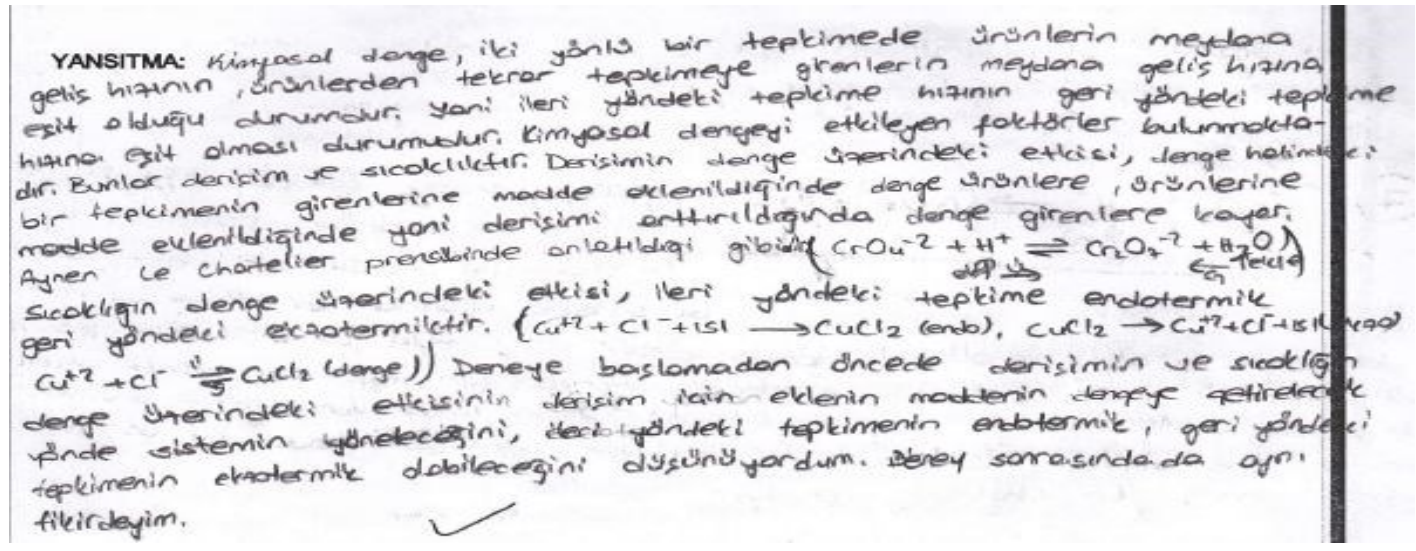

Şekil 18. Yansitma kısmı

Öğrenciden rapor yazımının son aşaması olarak son kavram haritasını oluşturması beklenir. Bu kavram haritası ile öğrencinin etkinlik ile bilgi dağarcığında nasıl bir gelişme olduğu gözlenebilir. Şekil 19 'de örnek son kavram haritası görülebilir. Burada öğrenci ön kavram haritasında olduğu gibi yine ağ kavram haritası çıkarmış, ön kavram haritasından farklı olarak sıcaklığın kimyasal dengeye etkisi ile ilgili yeni bağlantılar yapmış ve toplamda 12 kavram kullanmıştır.

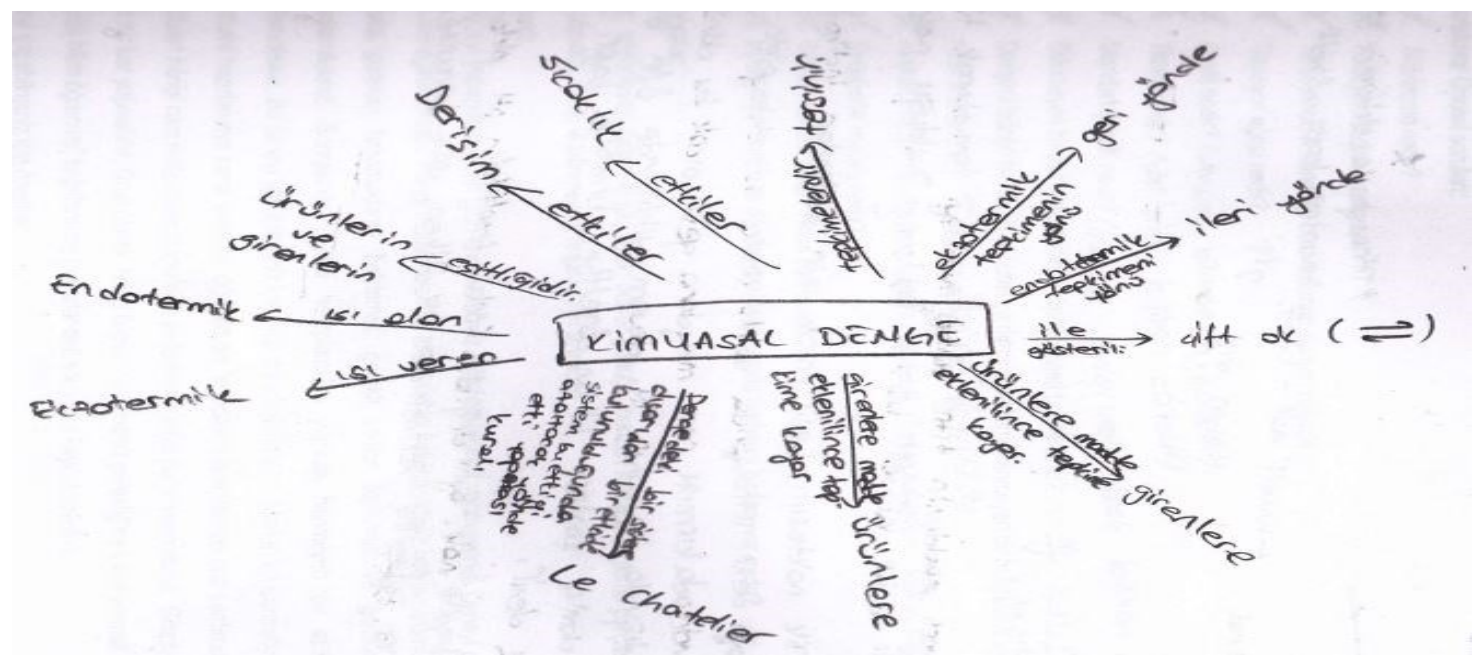

Şekil 19. Öğrenci son kavram haritası

\section{SONUÇ}

ATBÖ yaklaşımını teorik ve uygulamalı olarak açıklamaya çalışan bu makalede, uygulamanın getireceği faydalar ve uygulama esnasında dikkat edilmesi gereken hususlar aşağıda belirtilmiştir.

- Öğrencilerin deney yapma esnasındaki işbirlikçi katılımları, onların grup çalışmasının önemini anlamalarını ve öğrencilerin sadece öğretmenden değil arkadaşlarından da öğrenmelerine olanak sağlamaktadır.

- Öğrencilerin sınıf ortamında, başlangıç soruları, yöntem, gözlem, iddia ve kanıt aşamalarında yapmış oldukları bireysel, grup ve sınıf tartışmaları onların bilgilerin yapılanması sürecine katkı sağlamaktadır. Öğrencilerin her aşamada yaptıkları, öncül-gerekçelendirme-sonuçlandırma onların sözlü argümantasyon becerilerinin gelişmesine katkı sağlamaktadır. Ayrıca, ATBÖ yaklaşımının öğrenci şablonu öğrencilerin yazılı argümanlarını geliştirmektedir.

- Öğrencilerin yazılı ve sözlü argümanlarında yaptıkları iddia ve kanıtları desteklemek için kullandıkları kimyadaki çoklu gösterimler (makroskobik, mikroskobik, sembolik ve cebirsel seviye) onların bu dili etkin bir şekilde, doğal olarak kullanmalarını sağlamaktadır. Bu bağlamda, 
öğrencilerin dili etkin bir şekilde kullanmalarını sağlamak için, bu gösterimleri iddialarını kanıtlarken kullanmaları ve mantıklı cümleler halinde açıklama yapmaları sağlanabilir.

- Öğrencilerin ATBÖ öğrenci şablonu kullarak hazırladığı kısım, onların bilişsel ve üstbilişsel becerilerinin gelişmesine katkı sağlamaktadır. Bu bağlamda, öğrencilerin eleştirel düşünme düzeyinin zamanla gelişimi gözlenebilir. $\mathrm{Bu}$ süreç, öğrencilerin öğrenme beklentilerine ve deneyimlerine olumlu yönde etki eder.

ATBÖ için uygun öğrenme ortamları sağlamak adına öğretmenlerin uygulamada dikkate alacağı muhtemel noktalar aşağıdaki şekilde ifade edilebilir:

- Öğretmenlerin ATBÖ yaklaşımını etkili bir şekilde uygulayabilmeleri için epistemik yönelimlerini değiştirmeleri gerekmektedir. Bu bağlamda, ögretmenlerin öğrenme teorileri, dilin kullanımı ve bilimin doğası gibi konularda uygun epistemik yönelimlere sahip olması gerekir.

- Öğretmenler, öğrencilerin kültürlenme-odaklı ortamda, yaparak-yazarak öğrenme yaptıklarından dolayı argümantasyon (soru-iddia-kanıt) ve gösterim kullanmanın zaman alıyor olması dikkate alınmalıdır. Bu bağlamda, ögrenciye gerekli süre ve esneklik tanındığında farklı seviyedeki (alt, orta ve üst) öğrencilerin daha üst seviyelere çıtığı görülmektedir. 


\section{KAYNAKLAR}

Abd-El-Khalick, F., Boujaoude, S., Duschl, R., Lederman, N. G., Mamlok-Naaman, R., Hofstein, A., \& Tuan, H. L. (2004). Inquiry in science education: International perspectives. Science Education, 88(3), 397-419.

Akkus, R., Gunel, M., \& Hand, B. (2007). Comparing an inquiry-based approach known as the science writing heuristic to traditional science teaching practices: Are there differences?. International Journal of Science Education, 29(14), 1745-1765.

Bransford, J. D., Brown, A., \& Cocking, R. (1999). How people learn: Mind, brain, experience, and school. Washington, DC: National Research Council.

Burke, K. A., Greenbowe, T. J. \& Hand, B. M. (2005). Excerpts from the process of using inquiry and the science writing heuristic. Retrieved from http://avogadro.chem.iastate.edu/SWH/Resources.htm.

Burke, K. A., Hand, B., Poock, J., \& Greenbowe, T. (2005). Using the science writing heuristic. Journal of College Science Teaching, 35(1), 36-41.

Cavagnetto, A. R. (2010). Argument to foster scientific literacy: A review of argument interventions in K-12 science contexts. Review of Educational Research, 80(3), 336-371.

Chanlen, N. (2013). Longitudinal analysis of standardized test scores of students in the science writing heuristic approach (Unpublished doctoral thesis). The University of Iowa, Iowa City.

Choi, A., Hand, B., \& Greenbowe, T. (2013). Students' written arguments in general chemistry laboratory investigations. Research in Science Education, 43(5), 1763-1783.

Cikmaz, A. (2014). Examining two Turkish teachers' questioning patterns in secondary school science classrooms. The University of Iowa.

Demirbag, M., \& Gunel, M. (2014). Integrating Argument-Based Science Inquiry with Modal Representations: Impact on Science Achievement, Argumentation, and Writing Skills. Educational Sciences: Theory and Practice, 14(1), 386-391.

Driver, R., Newton, P., \& Osborne, J. (2000). Establishing the norms of scientific argumentation in classrooms. Science Education, 84(3), 287-312.

Duschl, R. (2008). Science education in three-part harmony: Balancing conceptual, epistemic, and social learning goals. Review of Research in Education, 32(1), 268-291.

Ford, M. J., \& Forman, E. A. (2006). Chapter 1: Redefining disciplinary learning in classroom contexts. Review of Research in Education, 30(1), 1-32.

Ford, M. J. (2012). A dialogic account of sense-making in scientific argumentation and reasoning. Cognition and Instruction, 30(3), 207-245.

Gee, J. P. (2004). Language in the science classroom: Academic social languages as the heart of school-based literacy. In Establishing scientific classroom discourse communities: Multiple voices of teaching and learning research. Lawrence Erlbaum Associates.

Greenbowe, T. J., \& Burke, K. A. (2008). Instruction by using the writing heuristic. Science inquiry, argument and language: A case for the science writing heuristic. Rotterdam, The Netherlands: Sense Publishers.

Günel, M., Memis, E. K., \& Büyükkasap, E. (2010). Effects of the Science Writing Heuristic Approach on Primary School Students' Science Achievement and Attitude toward Science Course. Egitim ve Bilim, 35(155), 49.

Haack, S. (2004). Epistemology legalized: Or, truth, justice, and the American way. The American Journal of Jurisprudence, 49, 43-61.

Hahn, L. L., \& Gilmer, P. J. (2000). Transforming pre-service teacher education programs with science research experiences for prospective science teachers. In annual meeting of the Southeastern Association for the Education of Teachers in Science, Auburn, AL.

Halliday, M.A.K. and Martin, J.R., 2003. Writing science: Literacy and discursive power. Taylor \& Francis.

Hand, B., \& Prain, V. (2006). Moving from border crossing to convergence of perspectives in language and science literacy research and practice. International Journal of Science Education, 28(2-3), 101-107.

Hand, B. M. (2008). Science inquiry, argument and language: A case for the science writing heuristic. Sense Pubns.

Hand, B., \& Choi, A. (2010). Examining the impact of student use of multiple modal representations in constructing arguments in organic chemistry laboratory classes. Research in Science Education, 40(1), 2944. 
Hand, B., Norton-Meier, L., \& Jang, J. Y. (2017). Examining the Impact of an Argument-Based Inquiry on the Development of Students' Learning in International Contexts. In More Voices from the Classroom (pp. 1-9). SensePublishers, Rotterdam.

Hand, B., Shelley, M. C, Laugerman, M., Fostvedt, L., \& Therrien, W. (2018) Improving critical thinking growth for disadvantaged groups within elementary school science: A randomized controlled trial using the Science Writing Heuristic approach. Science Education, 102(4), 693-710.

Kaya, O. N., (2003), Fen eğitiminde kavram haritaları, Pamukkale üniversitesi Eğitim Fakültesi Dergisi, 13, 70-79.

Keys, C. W., Hand, B., Prain, V., \& Collins, S. (1999). Using the science writing heuristic as a tool for learning from laboratory investigations in secondary science. Journal of Research in Science Teaching, 36(10), 10651084.

Kingir, S. (2011). Using the science writing heuristic approach to promote student understanding in chemical changes and mixtures (Yayınlanmamış dokrota tezi). Orta Doğu Teknik Üniversitesi, Ankara.

Kingir, S., Geban, O., \& Gunel, M. (2012). How does the science writing heuristic approach affect students' performances of different academic achievement levels? A case for high school chemistry. Chemistry Education Research and Practice, 13(4), 428-436.

Klein, P. D. (1999). Reopening inquiry into cognitive processes in writing-to-learn. Educational Psychology Review, 11(3), 203-270.

Klein, P. D. (2006). The challenges of scientific literacy: From the viewpoint of second-generation cognitive science. International Journal of Science Education, 28(2-3), 143-178.

Mason, L., \& Scirica, F. (2006). Prediction of students' argumentation skills about controversial topics by epistemological understanding. Learning and Instruction, 16(5), 492-509.

McNeill, K. L., Lizotte, D. J., Krajcik, J., \& Marx, R. W. (2006). Supporting students' construction of scientific explanations by fading scaffolds in instructional materials. The Journal of the Learning Sciences, 15(2), 153191.

Mercier, H., \& Sperber, D. (2011). Why do humans reason? Arguments for an argumentative theory. Behavioral and Brain Sciences, 34(2), 57-74.

MEB (2013). Milli Eğitim Bakanlığı Talim Terbiye Kurulu Başkanlığı, İlköğretim kurulları (ilkokullar ve ortaokullar) fen bilimleri dersi (3, 4, 5, 6, 7 ve 8. Sınıflar) öğretim programı. Ankara.

Nam, J., Choi, A., \& Hand, B. (2011). Implementation of the science writing heuristic (SWH) approach in 8th grade science classrooms. International Journal of Science and Mathematics Education, 9(5), 1111-1133.

National Research Council. (2007). Taking science to school: Learning and teaching science in grades K-8. National Academies Press.

National Research Council. (2012). A framework for K-12 science education: Practices, crosscutting concepts, and core ideas. National Academies Press.

Norris, S. P., \& Phillips, L. M. (2003). How literacy in its fundamental sense is central to scientific literacy. Science education, 87(2), 224-240.

Norton-Meier, L. (2008). Creating border convergence between science and language: A case for the Science Writing Heuristic. Science inquiry, argument and language: The case for the Science Writing Heuristic (SWH), 13-24.

Prain, V. (2006). Learning from writing in secondary science: Some theoretical and practical implications. International Journal of Science Education, 28(2-3), 179-201.

Prain, V., \& Hand, B. (2016). Coming to know more through and from writing. Educational Researcher, 45(7), 430-434.

Rogan, J., \& Aldous, C. (2005). Relationships between the constructs of a theory of curriculum implementation. Journal of Research in Science Teaching, 42(3), 313-336.

Sampson, V., Grooms, J., \& Walker, J. P. (2011). Argument-driven inquiry as a way to help students learn how to participate in scientific argumentation and craft written arguments: An exploratory study. Science Education, 95(2), 217-257.

Sandoval, W. A., \& Millwood, K. A. (2008). What can argumentation tell us about epistemology? In Erduran, S., \& Maria, P.J.(Eds), Argumentation in science education: perspectives from classroom-based research (pp. 68 - 85). Dordrecht, The Netherlands: Springer.

Wallace, C. S., Hand, B. B., \& Prain, V. (2004). Writing and learning in the science classroom (Vol. 23). Springer Science \& Business Media. 
Teoriden Uygulamaya Argümantaston Tabanlı Bilim Öğrenme (ATBÖ) Yaklaşımı: Kimya Laboratuvarlarında Uygulama Örneği

Walton, D. N. (1998). The new dialectic: Conversational contexts of argument. University of Toronto Press. Walton, D. (2016). Argument evaluation and evidence (Vol. 23). Springer.

Wellington, J., \& Osborne, J. (2001). Language and literacy in science education. McGraw-Hill Education (UK). Yeşildağ-Hasançebi, F., ve Günel, M. (2013). Argümantasyon tabanlı bilim öğrenme yaklaşımının dezavantajlı öğrencilerin fen bilgisi başarılarına etkisi. Ilköğretim Online, 12(4), 1056-1073.

Yore, L. D., \& Treagust, D. F. (2006). Current realities and future possibilities: Language and science literacyempowering research and informing instruction. International Journal of Science Education, 28(2-3), 291314. 